NISTIR 7784

\title{
Modeling and Simulation of Healthcare Systems for Homeland Security Applications
}

Charles McLean

Y. Tina Lee

Dr. Sanjay Jain

Dr. Charles Hutchings

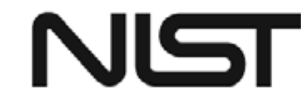


NISTIR 7784

\section{Modeling and Simulation of Healthcare Systems for Homeland Security Applications}

Charles McLean

Y. Tina Lee

Manufacturing Systems Integration Division

Engineering Laboratory

Dr. Sanjay Jain

George Washington University

Dr. Charles Hutchings

U.S. Department of Homeland Security

September 2011

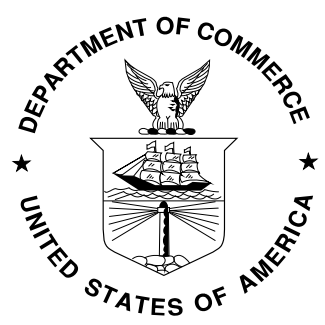

U.S. Department of Commerce Rebecca M. Blank, Acting Secretary

National Institute of Standards and Technology Patrick D. Gallagher, Under Secretary for Standards and Technology and Director 


\section{ACKNOWLEDGMENTS}

The U.S. Department of Homeland Security Science and Technology Directorate sponsored the production of this material under Interagency Agreements HSHQDC-09-X-00009 and HSHQDC-09-X00357 with the National Institute of Standards and Technology (NIST). The work described was funded by the United States Government and is not subject to copyright.

\section{DISCLAIMERS}

The findings expressed or implied in this report do not necessarily reflect the official view or policy of the U.S. Department of Homeland Security, U.S. Department of Commerce, or the United States Government.

Some software products may have been identified in context in this report. This does not imply a recommendation or endorsement of the software products by the authors or NIST, nor does it imply that such software products are necessarily the best available for the purpose.

Comments or questions about this report may be e-mailed to: simresponse@cme.nist.gov. 


\section{Contents}

1. Document Purpose .................................................................................................................... 1

2. Introduction to Healthcare Systems and Associated DHS Guidance ................................................ 2

3. Perspectives on Methodologies, Models, and Simulations............................................................... 5

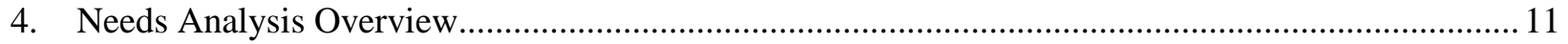

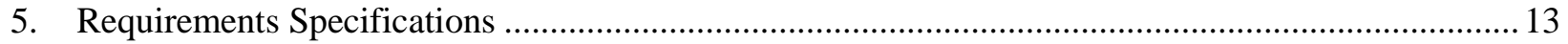

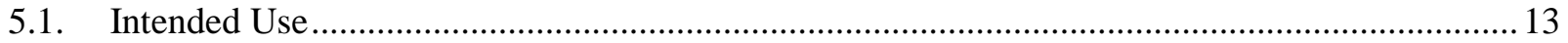

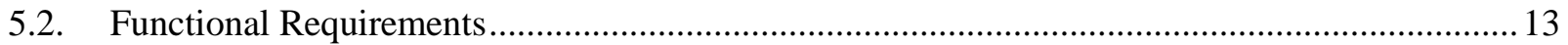

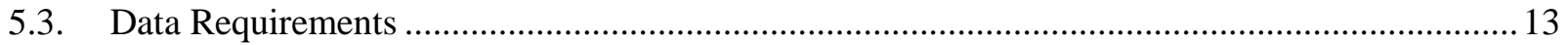

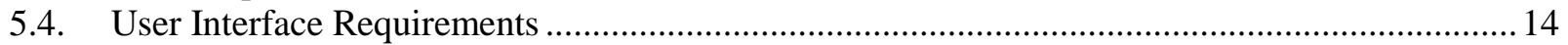

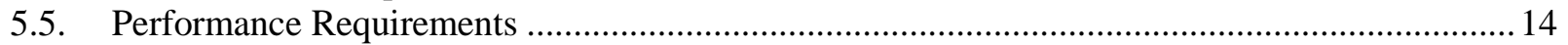

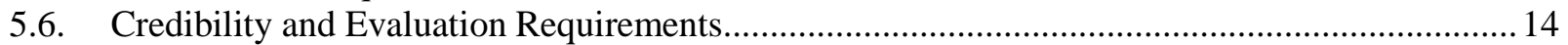

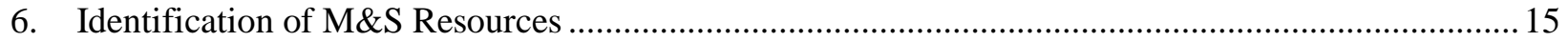

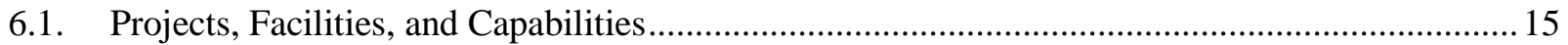

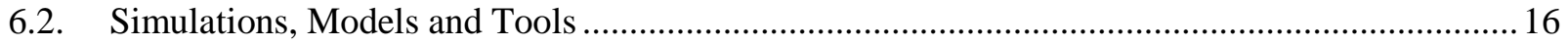

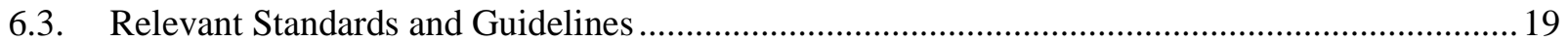

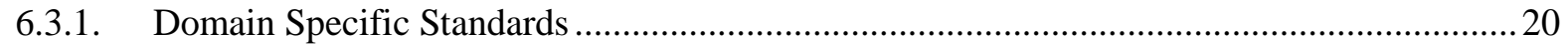

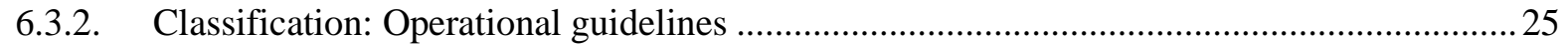

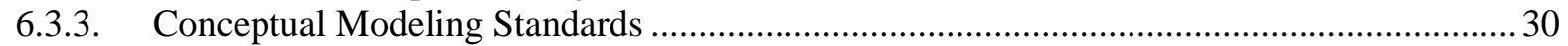

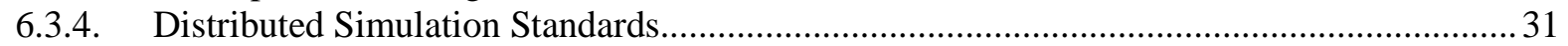

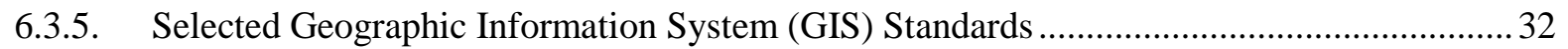

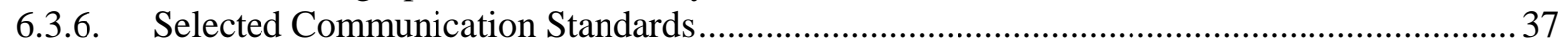

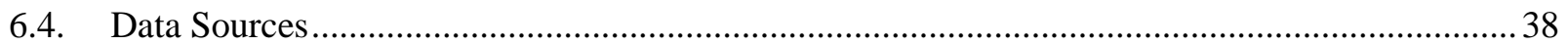

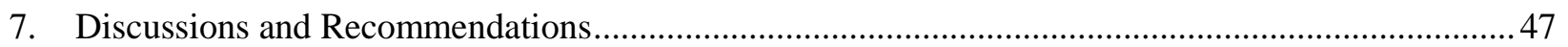

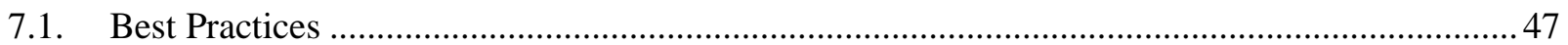

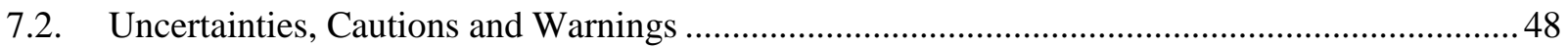

7.3. Research, Development, Standards, and Implementation Issues ........................................... 49

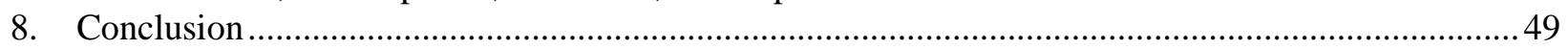

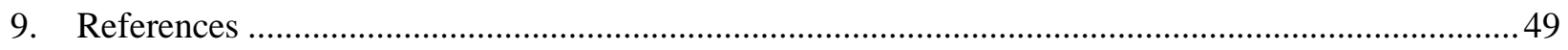


This page left blank intentionally. 


\section{Document Purpose}

Healthcare System models and simulations may be used to support analysis, planning, and training needs for the healthcare institutions, epidemics, and other healthcare-related emergencies. Simulation models may be used to understand healthcare systems, interdependencies with other systems, their vulnerabilities, and the impact of emergency incidents on the population and healthcare community. These models and simulations will also be used to support training exercises, performance measurement, conceptual design, impact evaluation, response planning, analysis, acquisition, conceptualizing and evaluating new systems, vulnerability analysis, economic impact, and determining interdependencies between healthcare and other infrastructure systems. The goal of this document is to capture the current knowledge and information resources that can serve as a common baseline for researchers and developers of models and simulations of healthcare systems for homeland security applications. This initial version of the document attempts to assemble relevant, publicly available information from a number of sources within U.S. Department of Homeland Security (DHS) and the modeling and simulation (M\&S) communities.

This document is intended to help initiate the discussion of the current leading research, development, standards, and implementation issues within the Healthcare System M\&S community, as it relates to homeland security. The document will be updated based on the input of domain experts across government, research, and commercial organizations. These experts will be invited to join together in a workshop to review and extend this document for its final publication. The workshop will focus on simulation and modeling activities and needs that support analysis, planning, and training for the healthcare systems as well as the integration of M\&S applications with each other and other data systems. Issues to be addressed within the scope of this workshop include the establishment of consensus on:

- identification of subject matter experts

- definition of customer and user needs

- $\quad$ system requirements specifications

- recommended/approved modeling techniques and approaches

- identification of data sources, reference data sets, formats, and standards

- identification of appropriate model evaluation and accreditation practices

The workshop will also help identify the current leading research, development, standards, and implementation issues. Such analysis by the workshop participants may be found to be relevant by future efforts for developing standards, conducting research and development, and enhancing implementation policies and procedures for homeland security applications of M\&S to improve the protection of critical infrastructure systems. A preliminary workshop that addressed modeling and simulation of healthcare systems was held in 2008, see [NIST 2010b] for further information.

This document provides a compendium of information that has been assembled that is relevant to the M\&S of healthcare systems. Healthcare systems, as pertains to homeland security, are introduced in Section 2. Section 3 provides a general background on methodologies, models, and simulations. An initial set of high level user and customer needs for M\&S applications in the healthcare system domain is presented in Section 4. Section 5 translates the high level needs to a representative set of M\&S system requirements (a more detailed specification is currently under development in a related effort). The existing healthcare systems M\&S resources and capabilities such as projects, tools, standards, and data sets that have been developed over the years to meet the needs and requirements are identified in Section 6. Section 7 presents a discussion of issues, concerns, and recommendations for advancing M\&S for healthcare systems emanating from a comparison of current resources and capabilities with the needs and requirements. Section 8 concludes the document while section 9 provides list of references used. 
Three additional documents have been prepared as a part of this effort. The other documents address M\&S for critical infrastructure and key resources (CIKR), incident management, and releases of hazardous materials. To minimize redundancy between the documents, each document focuses on the M\&S techniques that are most significant to the sectors mission and objectives. The CIKR document emphasizes modeling and simulation supporting analysis of systems (e.g., vulnerability, security), whereas the incident management document focuses more on training and exercises. The healthcare systems document addresses M\&S for analysis, training, and exercises, but at a more detailed level than the previous two documents. The hazardous material releases document focuses on the more physical aspects of M\&S associated with explosions, fires, plumes, and the flow of hazardous materials in building ventilation systems, bodies of water, and the soil. The authors recognize that each of the domains may employ all of the M\&S techniques that have been identified in the other documents, but typically to a lesser extent.

The authors welcome identification of omissions as well as suggestions for improvements. Please contact the authors directly or submit comments or questions by e-mail to simresponse@cme.nist.gov.

\section{Introduction to Healthcare Systems and Associated DHS Guidance}

The Healthcare and Public Health sector consists of state and local health departments, hospitals, health clinics, mental health facilities, nursing homes, blood-supply facilities, laboratories, mortuaries, and pharmaceutical stockpiles. The Responsible Agency for the healthcare sector, as designated in the relevant DHS documents, is the Department of Health and Human Services. Organizations that may be involved in addressing sector issues and as well the development of models and simulations include: Center for Disease Control, Food and Drug Administration, Department of Homeland Security (border control for foreign viruses, agricultural pests, etc.), Social Security Administration, the U.S. Public Health Service, state and local agencies, academic institutions, and research hospitals.

The healthcare systems domain includes modeling of incident victims and existing patients affected by incidents; medical symptoms, physiological processes, and behaviors that patients may experience as the result of a natural disaster, terrorist attack, or epidemic; disease management operations and procedures; the impact of disasters, etc. on the environment as well as the food supply (pollution, contamination, etc.). Issues that may be addressed by simulation applications include: analysis of policies, evaluation of options and predictions concerning the state of public health, spread of communicable diseases, policies for intervention, triage and priority scoring for surgeries or other treatments, vaccination programs, costeffectiveness analysis, medical emergency response, fatalities management, overall readiness of the healthcare system, hospitals and other related facilities/organizations, surge capacity, operational practices, logistic support systems, and elements of the pharmaceutical/equipment manufacturing sectors serving healthcare system needs.

Healthcare system models may be comprised of: representations of medical personnel and hospitals; constrained medical resources and work calendars; hospital facilities (operation theatres, intensive care units, beds); medical equipment, single use devices, and consumables; administrative documents and processes; medical procedures; the routing, status, and location of ambulances as well as other Emergency Medical Technician (EMT) resources and processes; the location, cost, status, quality, effectiveness, and dispensation of pharmaceuticals; and the logistics of industry practices and processes (climate controlled containers, other special needs). Models and simulations may be implemented as computer software, simulation-based training facilities (emergency and critical-care, medical/surgical patient care, maternity and pediatric rooms), and specialty devices (mannequins for various applications such as trauma, surgery and emergency care, disease diagnosis and treatment). 
DHS addresses healthcare systems in two contexts: a) as a function included in the response to emergencies in the context of incident management, and b) as a critical infrastructure sector that should be protected against efforts to affect its operation.

The National Incident Management System (NIMS) [DHS 2008a] and National Response Framework (NRF) [DHS 2008b] provide the relevant guidance for the incident management domain. Homeland Security Presidential Directive-5 (HSPD-5) [DHS 2003], called upon the Secretary of Homeland Security to develop a national incident management system (NIMS). The NIMS provides a systematic approach to guide all involved organizations through the entire life-cycle of preventing, protecting against, responding to, recovering from, and mitigating the effects of incidents while the NRF focuses on preparing for and providing a unified national response to incidents. NIMS, together with NRF and other documents, provides the structure needed to coordinate, integrate, and synchronize activities derived from various relevant statutes, national strategies, and Presidential directives to create a unified national approach to implementing the incident management mission (see Figure 1).

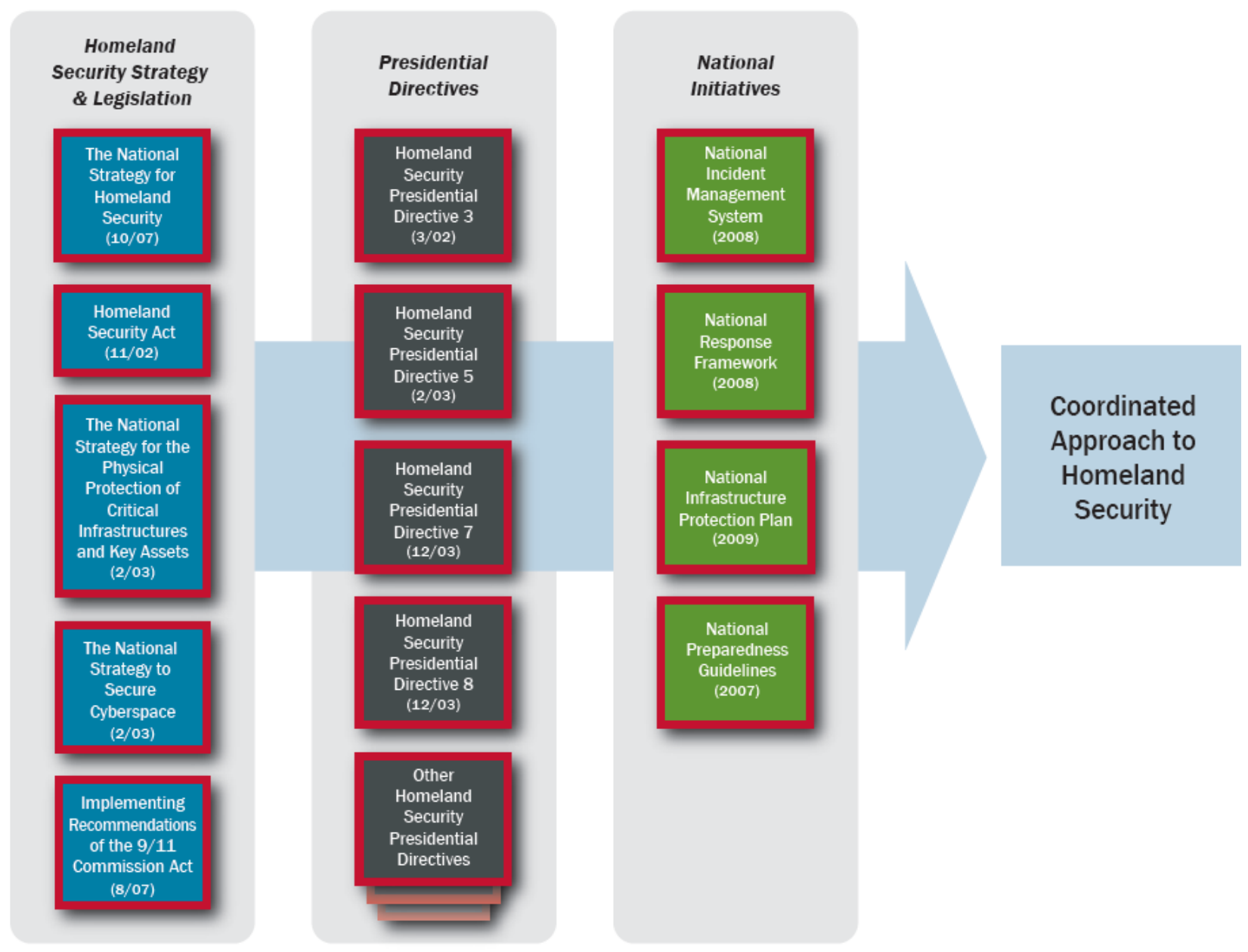

Figure 1: National Framework for Homeland Security (from [DHS 2009])

NIMS identifies that an incident may have a mix of implications including political, social, economic, environmental, public safety, public health, and financial, and hence require a coordinated response. For the healthcare systems perspective, the response includes collection of data on public health and environmental modeling using standard techniques. The public health information should be maintained 
securely given the sensitive nature of data. The information may be collected for investigations and analysis to determine the cause, projecting the spread, and selecting countermeasures for public health events and disease outbreaks. Typically M\&S application will be used for projections based on the collected information and for evaluating response strategies. Release of information on public health should be carefully managed by a public information officer.

NIMS defines the health and medical resource typing for resource management for incidents. The command staff may include a medical advisor for issues of medical and mental health services, mass casualty, acute care, vector control, epidemiology, or mass prophylaxis considerations, particularly in response to a bioterrorism incident. The command staff may also include public health specialists or radiation health specialist depending on the circumstances. Protocols should be developed for credentialing of volunteer management agencies such as the Red Cross, Medical Reserve Corps, etc. and by organizations such as hospitals. NIMS calls for setting up Area Command for public health emergencies since the impact may not be immediately identifiable, may be geographically dispersed and evolve over long periods of time.

In addition to concerns for the incident victims, the healthcare systems need to be concerned with the health of emergency responders. NIMS defines the need for addressing occupational health and mental issues for emergency responders including monitoring of immediate and long term effects of the incidents. The command staff should include a safety officer and/or an occupational safety and health specialist for monitoring and advising on the health and safety of incident personnel. The logistics section should include a medical unit for providing medical services to incident personnel.

The NRF [DHS 2008b] acknowledges that the responsibility for public health and welfare lies with the governments of the states, territories and tribal areas, and that they can request federal assistance if they anticipate their resources will be exceeded. Several federal departments do have the authority to declare disasters or emergencies. The Secretary of Health and Human Services (HHS) can declare a public health emergency. In a coordinated response, the states, territories and tribal governments should activate special response teams with a public health specialist should the incident warrant such action. The response is followed by short term recovery that includes providing essential public health and safety services. Restoration of healthcare services would usually include coordinating with private sector owner/operators. The NRF emergency support annexes provide primary operation level mechanism to provide assistance in functional areas including public health and medical services.

The NRF Emergency Support Function (ESF)\#8-Public Health and Medical Services specifically describes the federal coordinated response in case of a public health disaster or potential for one. It identifies HHS as the primary coordinator. The response addresses medical needs and other functional needs of people in the need of medical care. The ESF briefly describes the concept of operations and the organization for the ESF\#8 response. It defines initial actions such as, assessment of public health/ medical needs, health surveillance, providing medical care personnel, equipment, and supplies, patient evacuation and care, and mass fatality management. National Oceanic and Atmospheric Administration (NOAA) and Interagency Modeling and Atmospheric Assessment Center (IMAAC) may be called on for support in case of hazardous material releases being the cause of the emergency. ESF\#6- Mass Care, Emergency Assistance, Housing, and Human Services also calls for a large role for healthcare systems including emergency first aid and physical and mental health services for those in mass care. A number of other ESFs call for support roles dealing with public health.

The NRF also includes incident annexes that describe the specialized application of the response framework to specific situations. The incident annexes include those for biological, nuclear/ radiological, catastrophic, food and agriculture, and mass evacuation incidents. The focus of biological incident annex is on responding to human disease outbreaks of known and unknown origins with the HHS as the primary 
agency coordinating the response. The actions identified in the incident annex include HHS working with partner organizations to evaluate the incident. While the annex doesn't specifically mention it, M\&S can be used to predict the spread of the disease over time to help determine the areas and population at risk. All the other incident annexes include utilization of healthcare systems for caring for incident victims.

Related to the incident management context, the Homeland Security Presidential Directive-8 (HSPD-8) calls on DHS to develop mechanisms for improved delivery of Federal preparedness assistance to State, tribal and local governments [DHS 2008a]. Annex I to HSPD-8 provides guidance for planning and for the development of an integrated planning system. Fifteen national planning scenarios have been developed that may be used to help focus efforts to prepare for natural disasters, terrorist attacks, and other serious incidents. The national planning scenarios are Improvised Nuclear Device; Aerosol Anthrax; Pandemic Influenza; Plague; Blister Agent; Toxic Industrial Chemicals; Nerve Agent; Chlorine Tank Explosion; Major Earthquake; Major Hurricane; Radiological Dispersal Device; Improvised Explosive Device; Food Contamination; Foreign Animal Disease; and Cyber Attack. With the exception of cyber attack scenario, the rest of the scenarios will require the participation of the healthcare sector for preparedness, response and recovery. Also, a few of the scenarios, such as pandemic influenza and plague, require responses primarily involving healthcare systems. M\&S tools and applications should, wherever possible, support the modeling of healthcare systems in the fifteen national planning scenarios defined by DHS.

DHS has developed specific plans for all the critical infrastructure and key resources sectors. The sector specific plan for Healthcare and Public Health (HPH) identifies HHS as the sector specific agency [DHS 2011]. HPH sector is responsible for 15 percent of the gross national product. About $85 \%$ of the sector's assets are privately owned and operated. The public health component of the sector is managed across all levels of government from local to national. The HPH sector's vision has been stated as to achieve overall resiliency against all man-made and natural threats. HHS supported establishment of two councils, a Health Sector Coordinating Council for private sector component, and a Government Coordinating Council for the government sector. The councils have established collaborative workgroups on different topics such as, research and development needs and capability gaps for the sector, and measures and metrics for progress towards infrastructure protection goals. The HPH sector R\&D goals include strengthening of surge capacity modeling tools [HHS 2007], a goal that would strongly rely on M\&S techniques.

\section{Perspectives on Methodologies, Models, and Simulations}

Concise Oxford Dictionary of Current English, 1996, defines Methodology as "a body of methods used in a particular activity.” Methodology is principles of method, and such principles can be used to study and inform problem solving and decision-making. [Checkland 2000] describes a useful model linking methodology and the user of a methodology to problem solving:

'A problem-solving situation with three elements:

- A user of methodology (this assumes that the user is familiar with the methodology)

- Methodology as documented

- Situation as perceived by the user

Relationship and interactions between the three elements are encapsulated in the LUMAS model

(Learning, User of methodology, Methodology formally described, Actual approach adopted, and real world problem Situation) shown in figure 2. A simple example narrative for the diagram may be: A user, $U$, appreciating a methodology, $M$, as a coherent set of principles and perceiving a problem situation, S, asks, "what can I do?" The User then tailors from M a specific 
approach, $A$, judged to be appropriate for $S$, and uses it in an attempt to improve the situation. This generates learning, $L$, which may change the user, $U$ or the methodology, $M$.

A methodology is, then, a logical framework that not only brings forth learning for an individual, but does so in a consistent and systemic manner so learnings can be shared and passed on.'

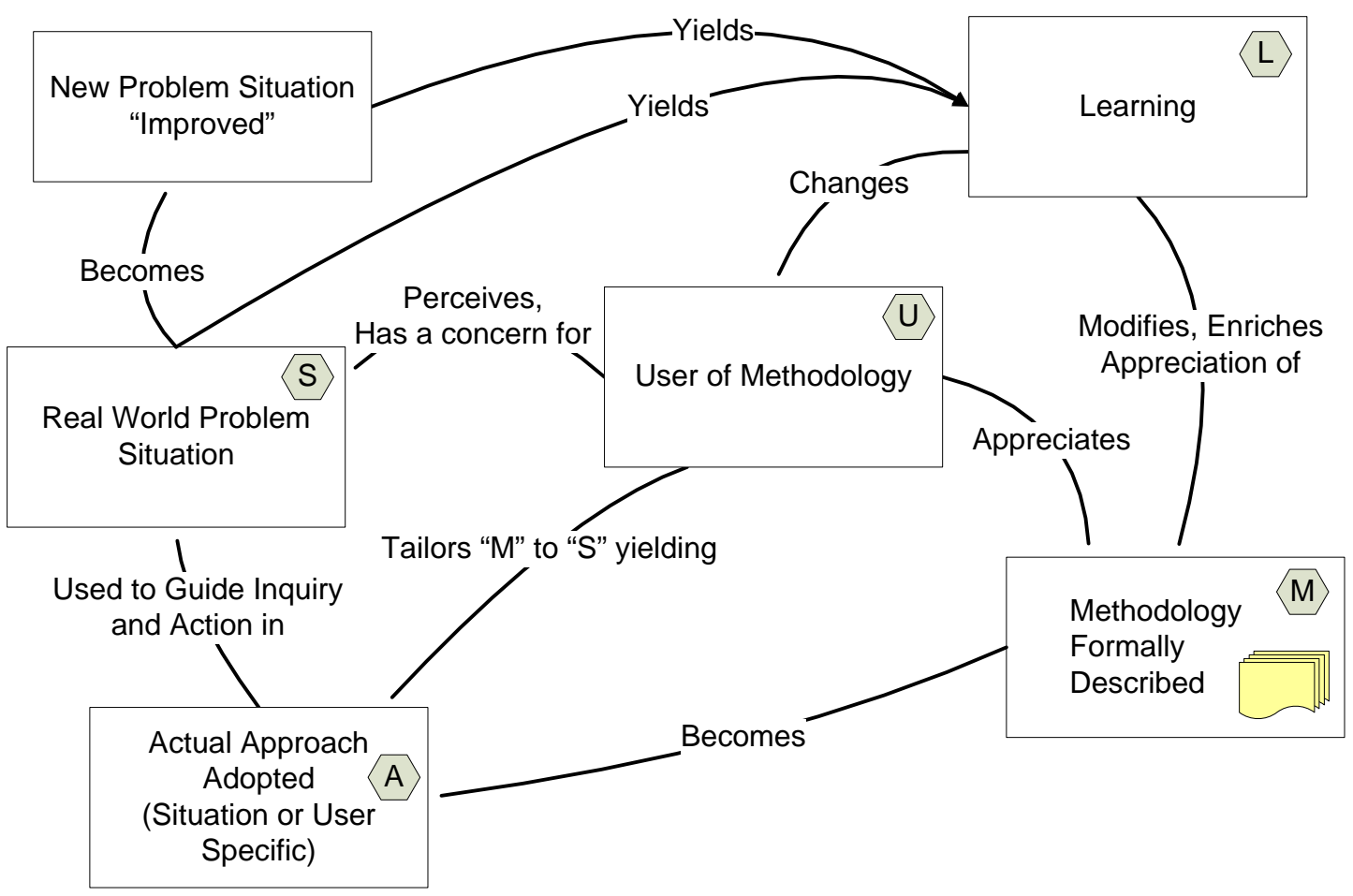

Figure 2: The LUMAS Model (from [Checkland 2000])

Another perspective on methodology comes from the International Council on Systems Engineering (INCOSE) where methodology is defined as "a collection of related processes, methods and tools" [INCOSE 2008]. This is based on definitions from [Martin 1996]:

'Methodology can be differentiated from other related concepts using the following definitions from [Martin 1996]:

- A Process $(P)$ is a logical sequence of tasks performed to achieve a particular objective. A process defines "WHAT" is to be done, without specifying "HOW" each task is performed. The structure of a process provides several levels of aggregation to allow analysis and definition to be done at various levels of detail to support different decision-making needs.

- A Method (M) consists of techniques for performing a task, in other words, it defines the "HOW" of each task. (In this context, the words: "method," "technique," "practice," and "procedure" are often used interchangeably.) At any level, process tasks are performed using methods. However, each method is also a process itself, with a sequence of tasks to be performed for that particular method. In other words, the "HOW" at one level of abstraction becomes the "WHAT" at the next lower level.

- A Tool (T) is an instrument that, when applied to a particular method, can enhance the efficiency of the task; provided it is applied properly and by somebody with proper skills and training. The purpose of a tool should be to facilitate the accomplishment of the "HOWs." In a broader sense, a tool enhances the "WHAT" and the "HOW." Most tools used to support 
systems engineering are computer- or software-based, and are also known as Computer Aided Engineering (CAE) tools.

Closely associated with methodology is an Environment (E) that consists of the surroundings, the external objects, conditions, or factors that influence the actions of an object, individual person or group [Martin 1996]. These conditions can be social, cultural, personal, physical, organizational, or functional. The purpose of a project environment should be to integrate and support the use of the tools and methods used on that project. An environment thus enables (or disables) the "WHAT" and the "HOW".'

The interrelationship of processes, methods, tools, and environments is graphically represented in Figure 3.
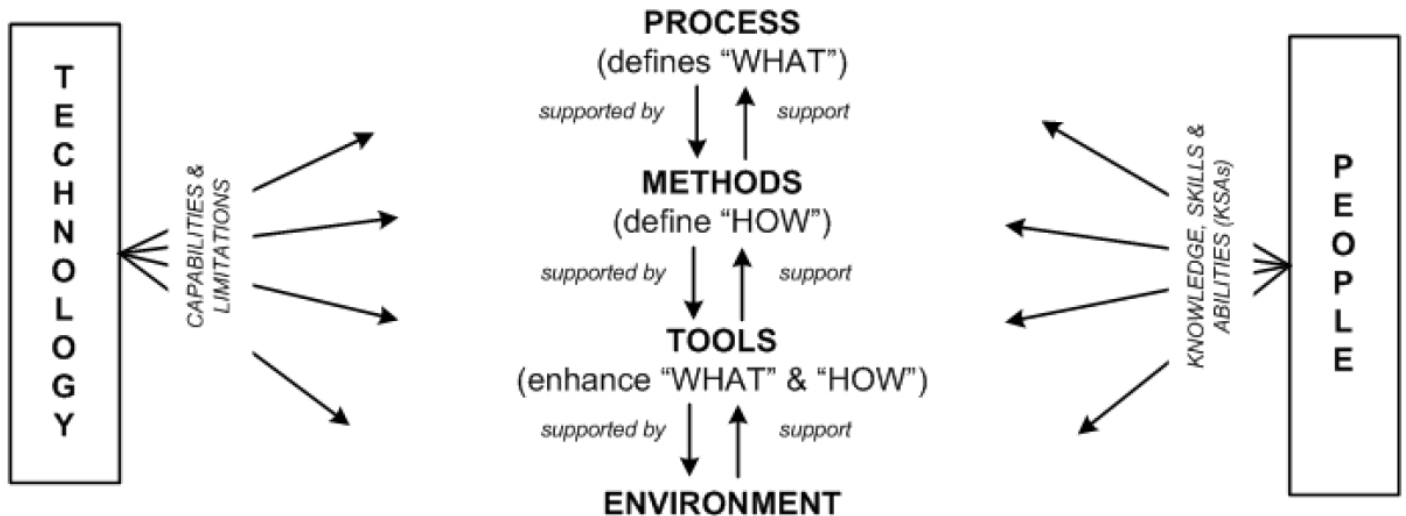

(enables/disables "WHAT \& "HOW")

Figure 3: The Process, Methods, Tools, Environments Elements, and Effects of Technology and People (from [INCOSE 2008])

"Model" and "simulation" can be defined or classified in many ways. For example, the DHS Lexicon [DHS 2010] includes the following definitions:

- Model: approximation, representation, or idealization of selected aspects of the structure, behavior, operation, or other characteristics of a real-world process, concept, or system.

- Simulation: model that behaves or operates like a given process, concept, or system when provided a set of controlled inputs.

In addition, Department of Defense glossary [DoD 2010] provides the following definition.

- Modeling \& Simulation: Modeling and Simulation (M\&S): The discipline that comprises the development and/or use of models and simulations. M\&S is highly dependent upon Information Technology as defined in DoD Directive 4630.05, Interoperability and Supportability of Information Technology (IT) and National Security Systems (NSS), May 5, 2004.

a. The use of models, including emulators, prototypes, simulators, and stimulators, either statically or over time, to develop data as a basis for making managerial or technical decisions. The terms "modeling" and "simulation" are often used interchangeably, but simulations generally execute models over time, space, events, or other processes. 
The focus of this document is on computer models and simulations - computer implemented physical, mathematical, process, phenomenological or other types of models. One perspective on the way in which computer models and simulations support methodology is modeled in Figure 4 (M in the LUMAS Model).

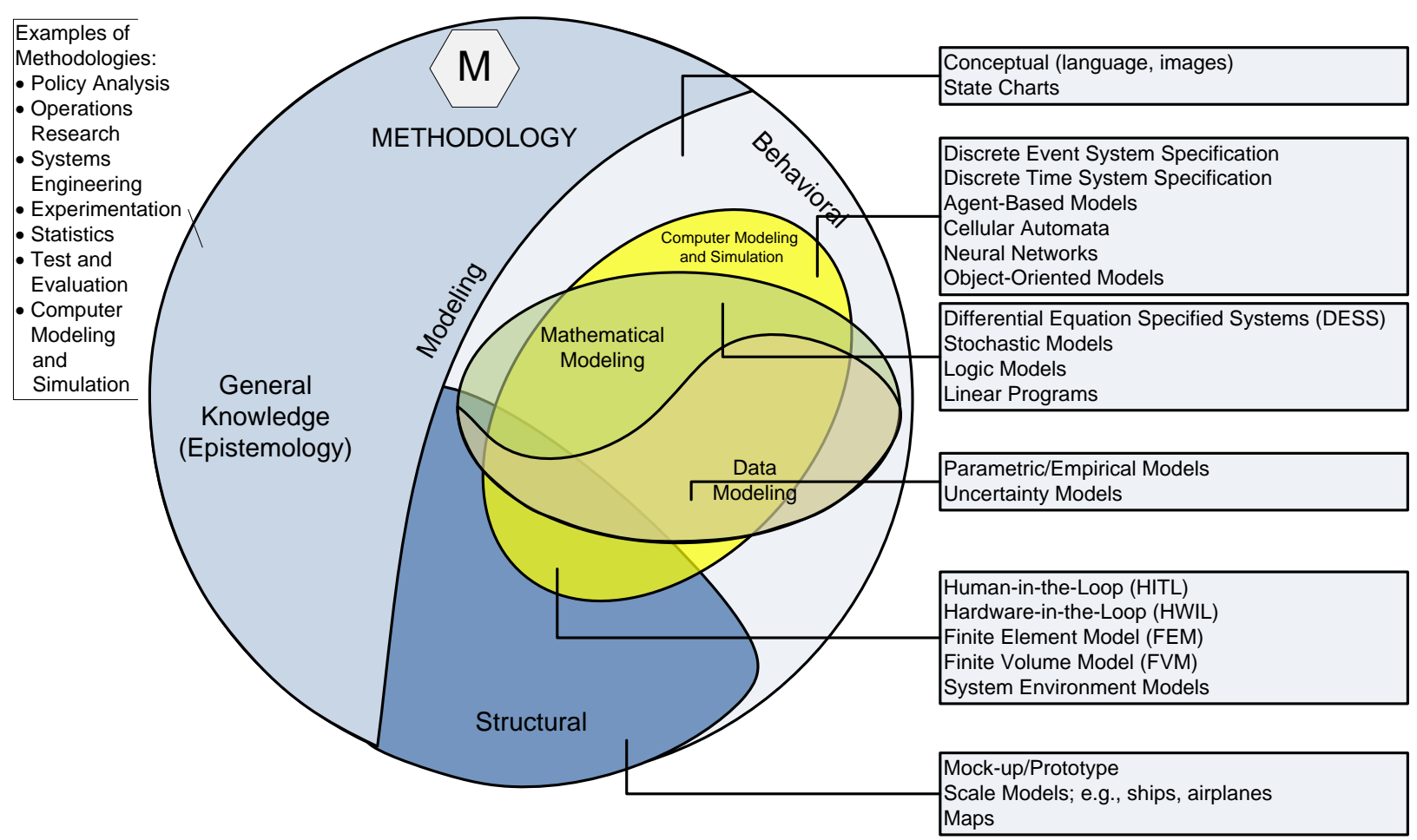

Figure 4: Modeling in methodology

Models can broadly be divided into structural and behavior representations of systems, which could include mathematical or empirical modeling. Each of these types of models can be implemented using computer models for simulation and used to study questions of interest about a particular system. Various examples of model types are shown. This list of model types is not complete or exhaustive, but is meant to show typical applications of M\&S that support methodologies such as operations research, systems engineering, experimentation, or other types of analysis.

Although M\&S capabilities are tools in many different methodologies, M\&S using computers is itself a methodology with supporting processes, methods and tools. Figure 5 illustrates a simplified, generic process for development of computational $\mathrm{M} \& \mathrm{~S}$ capabilities to address a non-trivial engineering or scientific problem from the perspective of an M\&S developer. The process shown in Figure 5 also maps to the LUMAS model as shown in the figure. This process is also applicable to simpler problems where trivial steps may be combined. Also, the $M \& S$ developer may be the problem solver and consumer of the M\&S results such as an engineer addressing a systems design question or a program manager doing a "what if' analysis to assess the risk to a program.

The first step in the process includes the model or code developer (U) developing a clear understanding of what problem situation (S) the consumer of the M\&S results is trying to address. A conceptual model of the system or problem serves as a framework in developing and implementing the appropriate computer 
modeling capability (A) using the M\&S methodology (M) to address the question at hand. With a clear conceptual model in mind, developers have a number of choices to make in generating results:

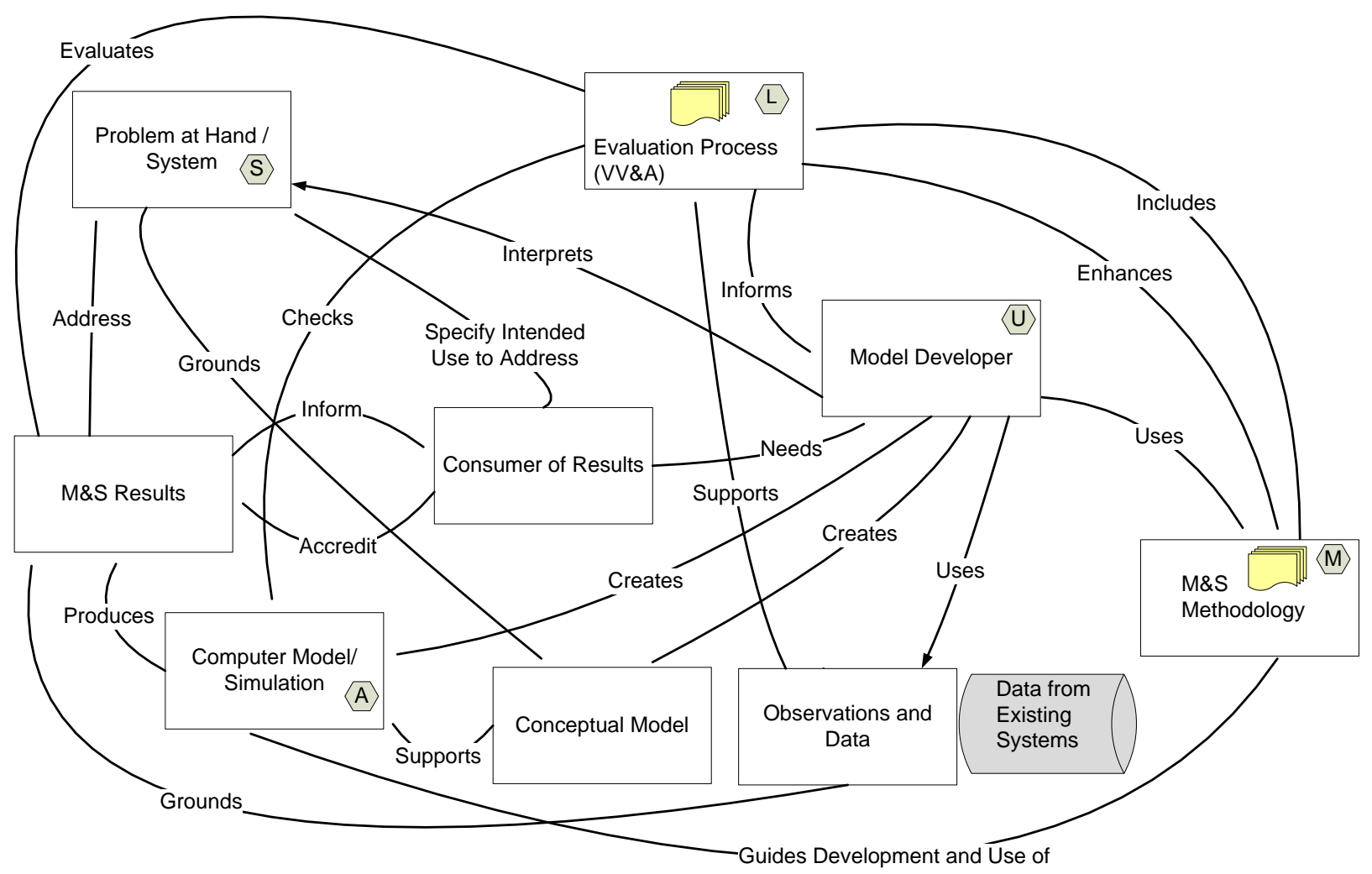

Figure 5: Computer Modeling and Simulation - Developer's Perspective

- What data, knowledge, theories, or models are available or applicable to address the problem at hand?

- Is the data, knowledge, or understanding sufficient in both quality and quantity to address the problem at hand, or will additional data or observations be required to support development?

- What is the risk of using erroneous results, e.g., will these results be the only input to a decision, or will other sources of information be available to support decision making?

- How can the conceptual model be expressed mathematically or physically?

- What boundary and initial condition should be used?

- What modeling paradigm or approach would be most appropriate to implement the analysis?

- Given the developers' experience, what particular codes or capabilities would be most suitable for implementing the model, considering software, hardware, and other constraints and limitations?

- Given the code or computer capability has been developed, have any mistakes or errors been made in completing this or in entering the data?

- Given there are no mistakes or errors found in developing the capability or entering the data, are the results realistic, and do they make sense?

- What approach should be used to ensure that the results are correct?

- How do uncertainties and approximations affect the computational results?

- Given that everything else is correct, are the results suitable to address the problem at hand?

- How should the results and associated uncertainty be present for use in decision making? 
M\&S capabilities are used to model only selected aspects of a system and the models are implemented in a computing environment; therefore, the models need to be critically evaluated to ensure that the results are credible for their specific intended use, and this is typically done using an evaluation process (L) which is included in the M\&S methodology (M) and informs the model developer (U) of the quality of the $M \& S$ capability and results in addressing the problem at hand (S).

Evaluation of M\&S capabilities and results should take into account the many factors that affect the quality of the results including the level of understanding or knowledge of the issues being addressed and the experience level of model developers. Several organizations have developed processes and guidelines to address the credibility of M\&S capabilities. For example, DoD has a process for documentation, evaluation, and certification of M\&S results known as Verification, Validation and Accreditation (VV\&A) that is defined in a recommended practice guide [DoD 2006]. The DoD process is implemented in policy, which develops a common understanding of the major steps in the VV\&A process defined as below [DoD 2009]:

- Verification. The process of determining that a model implementation and its associated data accurately represents the developer's conceptual description and specifications.

- Validation. The process of determining the degree to which a model and its associated data are an accurate representation of the real world from the perspective of the intended uses of the model.

- Accreditation. The official certification that a model, simulation, or federation of models and simulations and its associated data are acceptable for use for a specific purpose.

All M\&S capabilities should complete verification and validation (V\&V). M\&S capabilities used as the primary input to critical decision making, e.g., on cost, schedule, or performance of the system, should be formally accredited to certify that the results are credible for their intended use. Analysts and decisionmakers need to be aware of these sorts of issues when presented with computational modeling and simulation results.

[Balci 1998] developed a taxonomy and describes the use of different methods to evaluate M\&S capabilities and results based on software testing approaches. Figure 6 identifies these verification, validation, and testing methods or techniques which can be used to support an evaluation process such as VV\&A.

In addition to the use of recommended practices for conceptual modeling and ensuring model credibility, model developers should employ recommended practices for a number of other aspects. [Jain 2011] recommends best practices for modeling, simulation, and analysis for homeland security applications for the following aspects:

1. conceptual modeling

2. innovative approaches

3. software engineering

4. model confidence/ verification, validation and accreditation (VV\&A)

5. use of standards

6. interoperability

7. execution performance

8. user friendliness and accessibility 


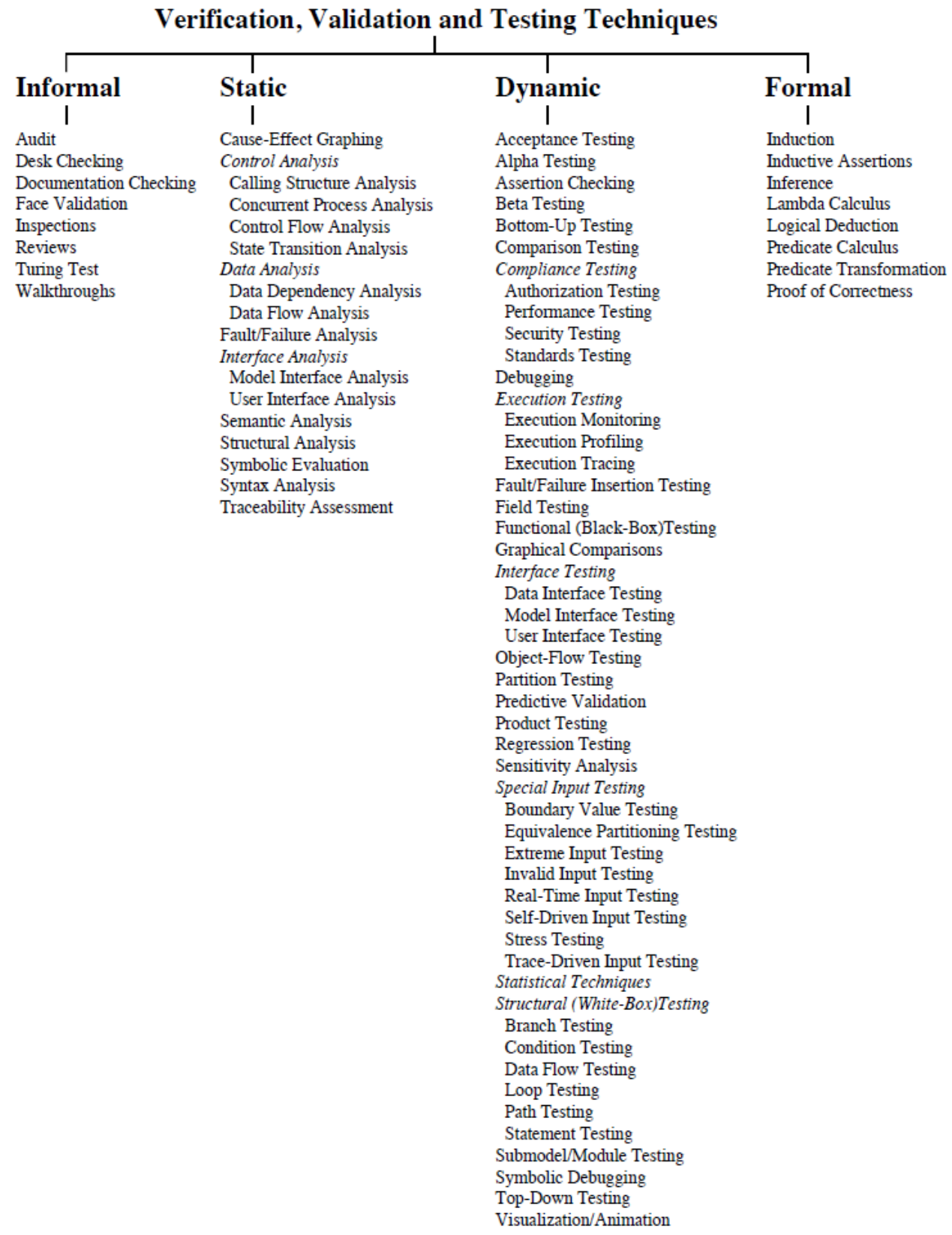

Figure 6: Taxonomy of Verification, Validation, and Testing Techniques (from [Balci 1998])

\section{Needs Analysis Overview}

Modeling and simulation should be used to support the needs of various managers, analysts, service providers, and first responders within the homeland security community. Most importantly, it must support the planning and response needs of the National Infrastructure Protection Plan (NIPP) partners including the Department of Homeland Security and other federal, state, local, tribal, territorial, and private sector organizations. The high level needs identified below have been derived from the National Infrastructure Simulation and Analysis Center (NISAC) mission statement, as well as a number of other DHS documents, and outside sources. An initial list of high level user/customer needs for healthcare M\&S follows: 
- Provide simulation and analysis capabilities to a wide range of users that will enhance the understanding of vulnerabilities, risks, and event consequences to healthcare systems.

- $\quad$ Provide M\&S capabilities to help establish priorities and potential mitigation strategies for protecting and/or isolating the impact of events on the population and healthcare systems.

- Provide models of the normal operations of healthcare systems, as well as the effects of epidemics, natural disasters, and terrorist attacks upon them to support analysis, planning, and response activities of homeland security healthcare system partners; predict economic impacts of disasters and other relevant healthcare events; support planning for facility defense and security, selection and placement of healthcare monitoring devices and system sensors to update status information, damage assessment, coordinated shutdown, and accelerated recovery of healthcare systems; establish healthcare models, simulations, and data sets that support the national planning scenarios.

- Provide decision-makers the ability to assess policy, investment, and resource allocation options that address healthcare systems needs - near and long term.

- Provide an integrating function that includes the identification and modeling of healthcare system interdependencies; supported interdependencies should include physical, geographic, cyber, and logical [Rinaldi 2004] enables the integration of national, regional, local systems and data sources; brings together disparate users, information providers, and individual infrastructure sector leaders.

- Move towards predictive capabilities that use science-based tools to understand the behavior and expected performance of interrelated infrastructures; predictive capabilities should support various conditions, healthcare systems, and event parameters such as time of day for events, level of demand for the healthcare system, system weaknesses, capacity of facilities, mobilization resources, surge capacity, temporary support organizations, their systems, and functions.

- Provide education and training to public and private decision-makers on how to cope effectively with crisis events.

- Establish virtual capabilities that provide portals for nation-wide remote access and communications to healthcare-related modeling, simulation, and analysis capabilities; identify data and interfaces needed for each healthcare model and event type; provide standard formats for the import and export of data between the portal and external data sources; help plan for the backup and/or remote siting of critical data sources outside of regions affected by events, e.g., hurricane disaster areas.

Other possible application scenarios that may help to define M\&S user needs and system requirements for healthcare systems include:

- Resource planning, capacity analysis, \& deployment

- Care prioritization and management

- Patient diagnosis, treatment, and other medical processing models

- Emergency medical response operations

- Layout of hospital facilities, departments, and processes

- Flow of health care documentation and information

- Mass preventative measures

- Public health strategies (quarantines, vaccinations)

- Coordination with other government agencies, HMOs, and other organizations

- Laboratory test procedures and identification of biological agents

- Decontamination and treatment for radiation exposure

- Media interactions for healthcare-related preventative activities and emergency incidents 


\section{Requirements Specifications}

This section translates the high level needs discussed in the previous section to a set of requirements. The requirements are intended to be common across all healthcare systems and hence at a high level. These requirements will serve as the starting set that may need to be enhanced for specific healthcare system for unique intended use. A separate document with a more detailed set of common requirements is being developed in a related effort.

\subsection{Intended Use}

Healthcare systems models and simulations will be used by healthcare organization managers, emergency planners, first responders, doctors and nurses, support and training personnel to:

a) Analyze the resource requirements, behavior, and performance of healthcare systems.

b) Conduct training exercises, drills, emergencies, tests, alerts, and support real world incidents (natural disasters, terrorist attacks, and epidemics).

c) Determine the readiness of healthcare systems to respond to various types of emergencies.

d) Model past incidents for education, training, and analysis purposes.

\subsection{Functional Requirements}

This section identifies possible functions that may be included in healthcare system models and simulations.

a) Provide functions to create high level models of healthcare system operations and evolutions over time to support system performance and resource analysis.

b) Provide training and exercise simulations for healthcare personnel that provide functionality for various incident and exercise parameters, exercise control, and after action reviews.

c) Provide various types of training implementations including tabletop exercises, 2D and 3D computer gaming, immersive virtual reality environments, training facilities, and mannequins.

d) Provide capabilities to refine simulations based on actual incident data, hospital usage data, medical assessments, and field measurements.

e) Support representations of geography, buildings, disease exposure and spread, lethality levels, healthcare institutions, equipment, personnel, victims, patients.

f) Support the integration and/or distributed execution of interrelated models including epidemics, hazardous material release exposure and hazard effects, critical infrastructure systems, incident management systems, and weather.

g) Identify regions where the exposed population will experience life threatening, serious long-lasting, or notable effects from incidents.

\subsection{Data Requirements}

This section identifies input and output data types that may be supported for healthcare models and simulations.

a) Structure of healthcare organizations and inventory of resources

b) Standard healthcare processes and procedures (e.g. triage and treatments)

c) Message logs and incident time lines

d) Specification of the incident area including event types and parameters, timing of events, schedule of responder and healthcare personnel activities, population, terrain and buildings in affected areas 
e) Demographics data: population location, density, and attributes by time of day

f) Meteorological data: observed and forecast weather conditions that may affect an incident including wind speed, direction, and precipitation

g) Plume data hazardous material releases and explosions

h) Support of appropriate data standards in model implementations, training and exercise simulations, e.g., SCORM - Shareable Content Object Reference Model [ADL 2011]

\subsection{User Interface Requirements}

This section identifies user interface capabilities that may be supported for healthcare system models and simulations.

a) Provide capabilities to configure simulation runs with specific incident types and associated parameters, affected populations, responder and healthcare system resources, weather conditions, and geographic regions.

b) Generate graphical views of incident, responder, and healthcare system activities over a 2D or 3D representation of area of interest at different levels of resolution.

c) Provide user control mechanisms that affect rapid execution/playback of simulation runs to move forward and back to desired points in time.

d) Use various DHS standard symbology, maps, and representation schemes to display incident parameters, resource locations, and timelines.

e) Provide virtual reality interfaces to support 3d gaming for healthcare exercises.

f) Provide exercise controller interfaces to effect the initiation, execution, as well as playback of exercise simulations for after action reviews and hot washes.

g) Provide interfaces to generate still image and video files that can be used to transfer results for viewing or playback using other software tools.

\subsection{Performance Requirements}

This section identifies possible performance considerations for healthcare system models and simulations.

a) Support time scaling of models and simulations and abilities to move forward rapidly in time to focus on events of interest (real-time for training and faster than real-time to support analysis during actual incidents and planning).

b) Provide for updates from real time epidemic, incident, meteorological databases and observations.

c) Share model predictions with other software applications.

d) Provide capabilities for interoperable networked implementations at different sites by different organizations.

\subsection{Credibility and Evaluation Requirements}

This section identifies approaches that may be used to evaluate and determine the credibility of healthcare models and simulations.

a) Conduct walkthroughs of simulation models of healthcare simulations and models with experienced healthcare personnel, incident managers and first responders.

b) Compare results and predictions of healthcare system models against past events using historical data.

c) Conduct side by side training exercises using conventional techniques (e.g., tabletop exercises) and computer-based simulations to compare effectiveness in achieving intended goals such as training objectives, realism, and exercise resource requirements. 


\section{Identification of $M \& S$ Resources}

This section identifies existing M\&S resources that support emergency healthcare systems and are possibly relevant to meeting some of the needs and requirements presented in sections 4 and 5 . Resources that primarily support other M\&S areas or domains, e.g., incident command, are not included. The section is divided into:

- $\quad$ Projects, Facilities, and Capabilities (6.1)

- Simulations, Models and Tools (6.2)

- Relevant Standards and Guidelines (6.3)

- Data Sources (6.4)

The term "simulation" is used to include a wide variety of modalities in healthcare area. The Center for Immersive and Simulation-based Learning (CISL) at Stanford School of Medicine [Stanford 2010] defines the following simulation modalities in the healthcare context: standardized patient actors, parttask physical trainers, virtual reality and visualization, desktop simulation and virtual worlds, and mannequin-based simulation. Modeling and simulation (M\&S), the focus of this report, has been defined to focus on computer based simulation and hence aligns primarily with the desktop simulation and virtual worlds and overlaps somewhat with the virtual reality and visualization modalities in CISL list. The subsections below hence primarily provide information relevant to the selected focus.

\subsection{Projects, Facilities, and Capabilities}

A number of projects and facilities focus on healthcare simulation. However a majority of them focus on standardized patient actors, part-task physical trainers, and mannequin-based simulation. A preliminary list of projects, facilities and capabilities that include the categories of our interest, i.e., desktop simulation and virtual worlds, and virtual reality and visualization, is provided below.

Center for Integration of Medicine and Innovative Technology (CIMIT) - CIMIT focuses on health care technologies, providing the resources and infrastructure to address technology application issues at the national and international level. CIMIT acts as a bridge between individual investigators and implementation of their ideas. It connects the investigators with a team of experts, and provides a nurturing collaborative environment to help the idea grow towards multiple uses, multiple partners, and multiple programs to address complex patient care problems. The work of simulation group at CIMIT includes building desktop simulation tools such as the Real-time Incident Preparedness Simulation (RIPS) [CIMIT 2010].

Complex Incident Response Training System (CIRTS)-Combat Medics (CM) project - MYMIC LLC is developing CIRTS-CM under a Small Business Innovation Research Phase II contract award in early December 2009. CIRTS-CM is a simulation game based training system for scene and patient management care following blast injuries sustained from explosives including Improvised Explosive Devices (IEDs). Eventually, CIRTS-CM support will expand to other medical domains, such as training combat lifesavers, individual soldiers and marines, military combat support hospitals, civilian emergency medical technicians, other emergency first responders and incidents other than IEDs [MYMIC 2010a].

NIH Center for Biomedical Computation at Stanford (Simbios) - Simbios is the NIH Center for physicsbased Simulation of Biological Structures. Simbios provides infrastructure, software, and training to help biomedical researchers understand biological form and function as they create novel drugs, synthetic tissues, medical devices, and surgical interventions. Simbios is investigating a wide scale of biological structures - from molecules to organisms. Driving biological problems include RNA folding, protein 
folding, myosin dynamics, cardiovascular dynamics, and neuromuscular biomechanics. Simbios is developing and disseminating the SimTK core simulation toolkit, an open-source software that includes capabilities for modeling the geometry and physics of biological systems. To ensure utility and accuracy, the software and training material is being developed and tested in close collaboration with biomedical scientists. Simbios has developed OpenSim, an application for advanced neuromuscular modeling that uses the SimTK toolkit, and is making it openly available [SIMBIOS 2010].

National Capital Area Medical Simulation Center - The SimCenter is part of the Uniformed Services University of the Health Sciences (USUHS) located in the Forest Glen Annex Silver Spring, Maryland. It has facilities for simulating medical procedures that are high risk or high consequence for patient safety. The simulations allow healthcare personnel develop and maintain the cognitive and psychomotor skills necessary to perform medical tasks safely and effectively. The Virtual Medical Environment Lab at the center includes surgical, emergency room and field hospital simulations, medical gaming as well as largescale simulations designed to train medical teams in battlefield and natural-disaster scenarios [USU 2010].

National Center for Collaboration in Medical Modeling and Simulation - The NCCMMS is a joint project of Eastern Virginia Medical School (EVMS) and Old Dominion University (ODU) and a variety of academic, governmental and commercial partners. Its mission is to improve both the quality and quantity of medical care available to U.S. military forces. This is accomplished by providing a collaborative environment where basic and applied medical modeling and simulation research can be undertaken by EVMS and ODU researchers within the context of a comprehensive academic medical center that provides a convenient clinical test bed for new technologies and approaches. The center has access to the expertise of the large U.S. military medical community as represented by the Naval Medical Center, Portsmouth, the Uniformed Services University of the Health Sciences, and other military medical facilities. Projects at NCMMS include homeland security, emergency training and response, and gaming simulations [EVMS 2009].

Medical Emergencies Simulation Lab, Institute for Simulation and Training, University of Central Florida - The lab builds on simulators developed by others to create sophisticated medical simulation capabilities that can enhance military, civil defense, and crisis management training. For example, the lab developed HLA-compliant software packages that allow simulated casualties generated during combat exercises to queue up for treatment by combat medics using a human patient simulator. The playing-fieldto-emergency treatment model also has been used to train EMTs in civilian mass casualty exercises [IST 2009].

\subsection{Simulations, Models and Tools}

A number of healthcare and epidemic modeling tools have been developed through the efforts of federal agencies, universities, research organizations and commercial companies. This section lists existing tools that have been identified through Internet searches and site visits to organizations involved in M\&S of healthcare systems. The tools are arranged alphabetically based on their developer's acronyms, or in some cases, abbreviations assigned by the authors for purposes of the readability of this document. Similar to the previous sub-section, the focus is on models and tools for desktop simulation and virtual worlds, and virtual reality and visualization.

\begin{tabular}{|l|l|}
\hline Tool Acronym & \multicolumn{1}{c|}{ Brief Description } \\
\hline Code Orange & $\begin{array}{l}\text { BreakAway developed a training simulation called "Code Orange” for the } \\
\text { Washington Hospital Center to train staff in the job roles they would have to assume } \\
\text { in a mass casualty incident. Based on job descriptions and tasked outlined in the }\end{array}$ \\
\hline
\end{tabular}




\begin{tabular}{|c|c|}
\hline & $\begin{array}{l}\text { Hospital Emergency Incident Command System (HEICS) protocol, this simulation } \\
\text { allows users to assume roles in triaging patients outside the hospital and inside the } \\
\text { ER [Breakaway 2010]. }\end{array}$ \\
\hline CVMDM & $\begin{array}{l}\text { Community Vaccination and Mass Dispensing Model (CVMDM) simulates the } \\
\text { allocation and distribution of pharmaceutical materials across a jurisdiction and the } \\
\text { dispensing of those materials through points of dispensing (PODs). Given a request } \\
\text { time for initial supplies from the Center for Disease and Prevention Control's } \\
\text { Strategic National Stockpile, estimated resupply intervals, population size and age } \\
\text { distribution, and POD personnel resources, the model calculates the estimated start } \\
\text { time for public vaccinations, POD queue times and throughput, and operation } \\
\text { closure. Linked with a disease progression submodel, CVMDM tracks and reports the } \\
\text { number of infections and fatalities based on disease characteristics and the } \\
\text { performance of prophylaxis supply logistics and PODs [ANL 2011]. }\end{array}$ \\
\hline$E D S$ & $\begin{array}{l}\text { ED Simulator (EDS) is a tool for Emergency Department throughput, staffing, patient } \\
\text { flow, and efficiency analysis. EDS combines the power and analytical capabilities of } \\
\text { simulation with database and data analysis technologies. It is designed to be used at } \\
\text { the unit Manager level as a tool for ongoing process analysis, continuous process } \\
\text { improvement, and accurate, objective internal benchmarking. It is based on } \\
\text { MedModel simulation "engine” [ProModel 2010a]. }\end{array}$ \\
\hline Edsim & $\begin{array}{l}\text { Edsim is a semi-reusable product to quickly model and test alternative design } \\
\text { scenarios for existing and proposed hospital emergency departments. It meets the } \\
\text { needs of hospital administrators to improve Key Performance Indicators (KPIs), such } \\
\text { as patient length of stay (LOS), bed utilization, elimination of bottlenecks, etc. } \\
\text { Edsim is also useful for predicting performance of proposed emergency departments } \\
\text { before finalizing architectural designs [Ferrin 2007]. }\end{array}$ \\
\hline EDSIM & $\begin{array}{l}\text { Emergency Department SIMulation (EDSIM) was developed through a cooperative } \\
\text { effort involving the University of California, Davis, Medical Center (UCDMC) } \\
\text { Department of Emergency Medicine and the UCDMC billing department using the } \\
\text { Extend Suite v.5 modeling platform developed by Imagine-That, Inc. It provides } \\
\text { modules that are connected by conduits that carry data elements representing } \\
\text { patients, staff, orders, laboratory results, images, etc. It combines continually updated } \\
\text { job queue prioritization and mid-task preemption capabilities that together allow the } \\
\text { model to capture the chaotic nature of ED staff activity [Connelly 2004]. }\end{array}$ \\
\hline ED Simulation & $\begin{array}{l}\text { ED Simulation is a desktop application designed specifically for quickly modeling } \\
\text { and simulating Emergency Departments. It reduces the programming by pre-building } \\
\text { Emergency Department workflow processes. Its applications include: minimizing } \\
\text { patient waiting times and ED overcrowding, identifying workflow "bottlenecks,”" } \\
\text { evaluating the effect of patient arrival and symptom mix, and testing disaster } \\
\text { preparedness scenarios [Loud Squirrel 2011]. }\end{array}$ \\
\hline EpiSimS & $\begin{array}{l}\text { The epidemic simulation engine, EpiSimS is a C++ application that runs on high- } \\
\text { performance computing clusters. It is stochastic agent-based discrete event model } \\
\text { that explicitly represents every person in a city, and every place within the city where } \\
\text { people interact. A city or region is represented physically by a set of road segment } \\
\text { locations and a set of business locations. EpiSimS can simulate various }\end{array}$ \\
\hline
\end{tabular}




\begin{tabular}{|c|c|}
\hline & $\begin{array}{l}\text { pharmaceutical and non-pharmaceutical interventions, including panic-based stay- } \\
\text { home behavior, therapeutic and prophylactic use of antivirals, contact tracing, } \\
\text { vaccination, wearing of masks, social distancing behaviors (increased inter-personal } \\
\text { separation, hand washing, cough etiquette, etc.), household quarantine, and closures } \\
\text { of schools [LANL 2010]. }\end{array}$ \\
\hline GameTT & $\begin{array}{l}\text { Games For Team Training (GaMeTT) is an immersive avatar based, virtual } \\
\text { environment designed for distributed medical team training. Participants log in to } \\
\text { GaMeTT from their own office or homes to work collectively towards team training } \\
\text { objectives, optimizing the time available for training and the opportunity for team } \\
\text { interaction. GaMeTT utilizes game-based technology to produce visually engaging } \\
\text { scenes, user friendly interfaces, and intuitive user commands. The tool is suitable for } \\
\text { distributed medical teams such as the Disaster Medical Assistance Teams (DMAT) } \\
\text { that are comprised of } 35 \text { volunteers who come together from different parts of the } \\
\text { country to form a team in case of a disaster [MYMIC 2010b]. }\end{array}$ \\
\hline HMS & $\begin{array}{l}\text { Healthcare Modeling Studio. A simulation modeling solution, is used to build custom } \\
\text { analysis tools for a variety of healthcare facilities, including emergency departments, } \\
\text { operating rooms, admissions, clinical labs and ancillary services. The tool can be } \\
\text { tailored to each client's specific processes, organization, terminology and metrics, } \\
\text { HMS helps healthcare professionals improve administrative and operational } \\
\text { efficiency, reduce cost and maximize ROI, validate process change or facility } \\
\text { expansion, and predict the impact of staffing changes or equipment upgrades [AAI } \\
\text { 2007]. }\end{array}$ \\
\hline LES & $\begin{array}{l}\text { Learning Environment Simulator (LES) developed at Los Alamos National Labs has } \\
\text { been built as an interface to Critical Infrastructure Protection Decision Support } \\
\text { System (CIPDSS). It is designed to engage decision makers at the grass-roots level } \\
\text { (local/city/state), deepen their understanding of an evolving crisis, enhance intuition } \\
\text { and let them test their own strategies. The initial version is based on a pandemic } \\
\text { influenza outbreak and has been tested with a group of hospital administrators and } \\
\text { first responders. LES is a simulated environment allowing the user to experience the } \\
\text { complexities of a crisis before it happens, including impacts to critical infrastructures } \\
\text { with their interdependencies and estimating human health \& safety and economic } \\
\text { impacts [LeClaire 2009]. }\end{array}$ \\
\hline MEDMODEL & $\begin{array}{l}\text { MedModel is a simulation tool designed specifically for the healthcare industry for } \\
\text { evaluation, planning and redesign of hospitals, clinics, and other healthcare systems. } \\
\text { MedModel models can be used to identify inefficiencies in an existing process and } \\
\text { test a variety of scenarios. Typical applications include: department specific } \\
\text { productivity improvement, facilities design (labs, clinics, radiology, emergency } \\
\text { rooms, etc.), planning for future changes, staff planning, analyzing patient capacity, } \\
\text { equipment planning and logistical analysis, emergency preparedness, and bed } \\
\text { capacity management [ProModel 2010b]. }\end{array}$ \\
\hline MUSTER & $\begin{array}{l}\text { MUSTER is a simulation tool for Multi-user Emergency Response training. } \\
\text { MUSTER supports training of doctors, nurses, Paramedics, EMT's, rescue workers, } \\
\text { disaster medicine rescue teams and others in disaster medicine and management. The } \\
\text { core of the training simulator is the patient model. The model has been developed by } \\
\text { Danish doctors, and is able to simulate a patient's condition dynamically based on the }\end{array}$ \\
\hline
\end{tabular}




\begin{tabular}{|l|l|}
\hline Optima Predict & $\begin{array}{l}\text { injuries and the treatment he receives. Patients in a scenario can be defined } \\
\text { individually [IFAD 2011]. } \\
\text { Optima predict is an interactive strategic planning solution for emergency services } \\
\text { that provides a platform for effective planning and simulation of requirements of } \\
\text { resources such as ambulances. Optima Predict takes into account key performance } \\
\text { indicators such as response times, vehicle types and coverage, shift rosters, post } \\
\text { locations and hospital ramp times to enable users to quickly build scenarios that make } \\
\text { logistical and business sense [Optima 2011]. }\end{array}$ \\
\hline PLAN C & $\begin{array}{l}\text { Planning with Large Agent-Networks against Catastrophes (PLAN C) is an agent } \\
\text { based simulation tool for emergency managers, urban planners and public health } \\
\text { officials to prepare and evaluate Pareto-optimal plans to respond to urban } \\
\text { catastrophic situations. PLAN C has been used to simulate emergency responses in } \\
\text { different urban catastrophic scenarios (e.g., chemical agent, bomb explosion, food } \\
\text { poisoning, small pox). It can devise plans that optimize multiple objective functions } \\
\text { (e.g., number of casualties, economic impact, time to recovery, etc.) in terms of their } \\
\text { Pareto frontier in a high-dimensional space; for this purpose, it uses an evolutionary } \\
\text { genetic search algorithm [NYU-CCPR 2009]. }\end{array}$ \\
\hline RIPS & $\begin{array}{l}\text { Real-time Incident Preparedness Simulation developed by the SimGroup at the } \\
\text { Center for the Integration of Medicine and Innovative Technology (CIMIT) is a } \\
\text { training tool for emergency response personnel. It is an incident simulator with game } \\
\text { like qualities and it provides a platform for creating disaster scenarios, sharing them, } \\
\text { and then training on them with other professionals. It is based on the NIMS hierarchy } \\
\text { [CIMIT 2002]. }\end{array}$ \\
$\begin{array}{l}\text { SimCare Process Simulator 9.0 is a process simulation software for the healthcare } \\
\text { industry. SimCare pro healthcare simulation includes support for hospitals, clinics, } \\
\text { and blood centers. It allows for importing CAD files for the facilities such as } \\
\text { emergency departments, and historical data for rapid model development of the } \\
\text { model [CreateASoft 2011]. }\end{array}$ \\
\hline Simere
\end{tabular}

\subsection{Relevant Standards and Guidelines}

This section identifies standards and guidelines that are potentially relevant to the development of M\&S applications for healthcare systems. The standards and guidelines may include mechanisms and formats for the interchange of data, data storage, generation of information displays, integration of systems, and/or conceptualization and design of healthcare M\&S applications. Subsection 1 includes the standards that are specific to healthcare domain. The following subsections list standards that are common across the homeland security applications of M\&S and focus on conceptual modeling, distributed simulation, geographical information system (GIS), and communications respectively. 


\subsubsection{Domain Specific Standards}

\begin{tabular}{|c|c|}
\hline Standard Title & Overview \\
\hline $\begin{array}{l}\text { After a Terrorist Bombing: Health } \\
\text { and Safety Information for the } \\
\text { General Public }\end{array}$ & $\begin{array}{l}\text { Description: A document contains "Immediately after the } \\
\text { event” and "Hours or days after the event” for helping people } \\
\text { who have been affected by the blast and will provide updated } \\
\text { information as soon as they learn more [CDC 2010a]. } \\
\text { Standard Type: N/A } \\
\text { Organization: The Centers for Disease Control and Prevention } \\
\text { (CDC) } \\
\text { Classification: Operational guidelines }\end{array}$ \\
\hline $\begin{array}{l}\text { Bioterrorism Readiness Plan: } A \\
\text { Template for Healthcare Facilities }\end{array}$ & $\begin{array}{l}\text { Description: A Bioterrorism Readiness Plan to serve as a } \\
\text { reference document and initial template to facilitate preparation } \\
\text { of bioterrorism readiness plans for individual institutions [CDC } \\
\text { 2010b]. } \\
\text { Standard Type: N/A } \\
\text { Organization: The Centers for Disease Control and Prevention } \\
\text { (CDC), The Association for Professionals in Infection Control } \\
\text { and Epidemiology (APIC) Bioterrorism Task Force } \\
\text { Classification: Operational guidelines }\end{array}$ \\
\hline $\begin{array}{l}\text { Business Continuity/Disaster } \\
\text { Recovery Plan }\end{array}$ & $\begin{array}{l}\text { Description: The business continuity/disaster recovery plan is } \\
\text { to identify the most critical information needs for patient care, } \\
\text { treatment, and services and business processes, and the impact } \\
\text { on the hospital if these information systems were severely } \\
\text { interrupted. The plan identifies alternative means for processing } \\
\text { data, providing for recovery of data, and returning to normal } \\
\text { operations as soon as possible [JCAHOSTD 2010]. } \\
\text { Standard Type: IM.2.30 (2008) } \\
\text { Organization: The Joint Commission } \\
\text { Classification: Operational guidelines }\end{array}$ \\
\hline $\begin{array}{l}\text { Common Biometric Exchange } \\
\text { Formats Framework (CBEFF) }\end{array}$ & $\begin{array}{l}\text { Description: The standard specifies a common set of data } \\
\text { elements necessary to support multiple biometric technologies } \\
\text { and to promote interoperability of biometric-based application } \\
\text { programs and systems by allowing for biometric data exchange. } \\
\text { These common data elements can be placed in a single file, re- } \\
\text { cord, or data object used to exchange biometric information } \\
\text { between different system components and applications. This } \\
\text { standard specifies the biometric data elements [ANSI 2010]. } \\
\text { Standard Type: ANSI INCITS 398-2008 } \\
\text { Organization: American National Standards Institute (ANSI) } \\
\text { Classification: Document Format }\end{array}$ \\
\hline $\begin{array}{l}\text { Communicating in the First Hours } \\
\text { for Anthrax: Short and Extended } \\
\text { Messages }\end{array}$ & $\begin{array}{l}\text { Description: These messages can be used by public health } \\
\text { officials during the first hours after a suspected anthrax } \\
\text { emergency. The short messages include essential information to } \\
\text { help minimize the immediate risk to the public from an attack. } \\
\text { The extended messages also include general information that }\end{array}$ \\
\hline
\end{tabular}




\begin{tabular}{|c|c|}
\hline & $\begin{array}{l}\text { can be used as a resource for officials in developing messages } \\
\text { tailored to a specific situation [CDC 2010c]. } \\
\text { Standard Type: N/A } \\
\text { Organization: The Centers for Disease Control and Prevention } \\
\text { (CDC) } \\
\text { Classification: Operational guidelines }\end{array}$ \\
\hline $\begin{array}{l}\text { Community-Based Mass } \\
\text { Prophylaxis: A Planning Guide for } \\
\text { Public Health Preparedness }\end{array}$ & $\begin{array}{l}\text { Description: Planning guide to help state, county, and local } \\
\text { officials meet federal requirements to prepare for public health } \\
\text { emergencies [AHRQ 2010a]. Outlines five components of mass } \\
\text { prophylaxis response to epidemic outbreaks. Addresses } \\
\text { dispensing operations using a comprehensive operational } \\
\text { structure for Dispensing/Vaccination Centers (DVCs) based on } \\
\text { the National Incident Management System (NIMS). } \\
\text { Standard Type: N/A } \\
\text { Organization: The Agency of Healthcare Research \& Quality } \\
\text { (AHRQ) } \\
\text { Classification: Operational guidelines }\end{array}$ \\
\hline $\begin{array}{l}\text { Digital Imaging and } \\
\text { Communications in Medicine } \\
\text { (DICOM) }\end{array}$ & $\begin{array}{l}\text { Description: A specification for exchange of radiology images } \\
\text { and other medical information between computers. It enables } \\
\text { digital communication between diagnostic and therapeutic } \\
\text { equipment and systems from various manufacturers. DICOM is } \\
\text { a global Information-Technology that is used in virtually all } \\
\text { hospitals worldwide. Its current structure is designed to ensure } \\
\text { the interoperability of systems to produce, store, display, } \\
\text { process, send, retrieve, query or print medical images and } \\
\text { derived structured documents as well as to manage related } \\
\text { workflow [NEMA 2010]. } \\
\text { Standard Type: DICOM 3.0 } \\
\text { Organization: American College of Radiology (ACR), and } \\
\text { National Electrical Manufacturers Association (NEMA) } \\
\text { Classification: General purpose integration interfaces }\end{array}$ \\
\hline Disaster Privileges & $\begin{array}{l}\text { Description: A plan that identifies the option to grant privileges } \\
\text { during disaster situations to doctors and other licensed } \\
\text { practitioners [JCAHOSTD 2010]. } \\
\text { Standard Type: MS.4.110; HR.4.35 } \\
\text { Organization: The Joint Commission Resources } \\
\text { Classification: Operational guidelines }\end{array}$ \\
\hline $\begin{array}{l}\text { Drawing Interchange File (DXF) } \\
\text { Formats }\end{array}$ & $\begin{array}{l}\text { Description: The DXF format is a tagged data representation of } \\
\text { all the information contained in an AutoCAD drawing file. } \\
\text { Tagged data means that each data element in the file is preceded } \\
\text { by an integer number that is called a group code. A group code's } \\
\text { value indicates what type of data element follows. This value } \\
\text { also indicates the meaning of a data element for a given object } \\
\text { (or record) type. Virtually all user-specified information in a } \\
\text { drawing file can be represented in DXF format [AUTODESK } \\
\text { 2010]. DXF can be used for exchange of radiology images and }\end{array}$ \\
\hline
\end{tabular}




\begin{tabular}{|c|c|}
\hline & $\begin{array}{l}\text { other medical information between computers. } \\
\text { Standard Type: AutoCAD 2009, v.u.23.1.01 } \\
\text { Organization: Autodesk, Inc. } \\
\text { Classification: General purpose integration interfaces }\end{array}$ \\
\hline Emergency Electrical Power Source & $\begin{array}{l}\text { Description: A plan that describes the requirements of a } \\
\text { hospital's emergency power system [JCAHOSTD 2010]. } \\
\text { Standard Type: EC. } 7.20 \\
\text { Organization: The Joint Commission Resources } \\
\text { Classification: Operational guidelines }\end{array}$ \\
\hline Emergency Management Drills & $\begin{array}{l}\text { Description: A plan that describes a hospital's approach to } \\
\text { conduct drills to test emergency management [JCAHOSTD } \\
\text { 2010]. } \\
\text { Standard Type: EC. } 4.20 \\
\text { Organization: The Joint Commission Resources } \\
\text { Classification: Operational guidelines }\end{array}$ \\
\hline Emergency Management Planning & $\begin{array}{l}\text { Description: An emergency management plan that } \\
\text { comprehensively describes the approach to emergencies in the } \\
\text { hospital or its community [JCAHOSTD 2010]. } \\
\text { Standard Type: EC.4.10 } \\
\text { Organization: The Joint Commission Resources } \\
\text { Classification: Operational guidelines }\end{array}$ \\
\hline Environment of Care Crosswalk & $\begin{array}{l}\text { Description: The Joint Commission Resources, a not-for-profit } \\
\text { affiliate of The Joint Commission, released the Environment of } \\
\text { Care Crosswalk. The } 2009 \text { Environment of Care Crosswalk } \\
\text { helps hospitals to simplify their compliance activities and } \\
\text { recognize when there is a duplication of requirements between } \\
\text { the Joint Commission } 2009 \text { Environment of Care, Emergency } \\
\text { Management, and Life Safety Standards, and the regulations of } \\
\text { the Occupational Safety and Health Administration (OSHA), the } \\
\text { Environmental Protection Agency (EPA) [JCR 2010]. } \\
\text { Standard Type: 2009 Environment of Care } \\
\text { Organization: The Joint Commission Resources } \\
\text { Classification: Operational guidelines }\end{array}$ \\
\hline $\begin{array}{l}\text { Facts About the Laboratory } \\
\text { Response Network }\end{array}$ & $\begin{array}{l}\text { Description: Description of the network of labs that respond to } \\
\text { biological \& chemical terrorism. In 1999, the Centers for } \\
\text { Disease Control and Prevention (CDC) established the } \\
\text { Laboratory Response Network (LRN). The LRN's purpose is to } \\
\text { run a network of labs that can respond to biological and } \\
\text { chemical terrorism, and other public health emergencies. The } \\
\text { LRN has grown since its inception. It now includes state and } \\
\text { local public health, veterinary, military, and international labs. } \\
\text { This fact sheet provides a brief description of the LRN, and how } \\
\text { it works [CDC 2010d]. } \\
\text { Standard Type: N/A } \\
\text { Organization: The Centers for Disease Control and Prevention }\end{array}$ \\
\hline
\end{tabular}




\begin{tabular}{|c|c|}
\hline & $\begin{array}{l}\text { (CDC) } \\
\text { Classification: Operational guidelines }\end{array}$ \\
\hline $\begin{array}{l}\text { Guidance for Protecting Building } \\
\text { Environments from Airborne } \\
\text { Chemical, Biological, or } \\
\text { Radiological Attacks }\end{array}$ & $\begin{array}{l}\text { Description: This document identifies actions that a building } \\
\text { owner or manager can implement without undue delay to } \\
\text { enhance occupant protection from an airborne chemical, } \\
\text { biological, or radiological attack [CDC 2010e]. } \\
\text { Standard Type: N/A } \\
\text { Organization: The National Institute for Occupational Safety \& } \\
\text { Health (NIOSH); The Centers for Disease Control and } \\
\text { Prevention (CDC) } \\
\text { Classification: Operational guidelines }\end{array}$ \\
\hline $\begin{array}{l}\text { Guidance for Public Health } \\
\text { Departments and Clinicians Caring } \\
\text { for Individuals Who May Have Been } \\
\text { Recently Exposed to Polonium -210 }\end{array}$ & $\begin{array}{l}\text { Description: Clinical guidance recommendations for public } \\
\text { health departments and clinicians to care people who may have } \\
\text { been recently exposed to Polonium -210 (Po-210). Po-210 is } \\
\text { considered to be one of the most hazardous radioactive materials } \\
\text { known, but it must be inhaled or ingested to exert its toxic } \\
\text { effects. It is found naturally in the environment, and the general } \\
\text { population is internally contaminated with small but measurable } \\
\text { amounts of it on a regular basis through food, water, and air } \\
\text { [CDC 2010f]. } \\
\text { Standard Type: N/A } \\
\text { Organization: The Centers for Disease Control and Prevention } \\
\text { (CDC) } \\
\text { Classification: Operational guidelines }\end{array}$ \\
\hline $\begin{array}{l}\text { Guidance on Initial Responses to a } \\
\text { Suspicious Letter/Container With a } \\
\text { Potential Biological Threat }\end{array}$ & $\begin{array}{l}\text { Description: Guidelines for local responders, based on existing } \\
\text { procedures, on the initial response to letters, packages, or } \\
\text { containers containing suspicious powders, liquids, or other } \\
\text { materials [DHS 2010b]. } \\
\text { Standard Type: N/A } \\
\text { Organization: The Centers for Disease Control and Prevention } \\
\text { (CDC), Federal Bureau of Investigation (FBI), Department of } \\
\text { Homeland Security (DHS) } \\
\text { Classification: Operational guidelines }\end{array}$ \\
\hline $\begin{array}{l}\text { Guidelines for Handling Decedents } \\
\text { Contaminated with Radioactive } \\
\text { Materials }\end{array}$ & $\begin{array}{l}\text { Description: Detonation of a nuclear weapon or activation of a } \\
\text { radiological dispersal device could cause radioactively } \\
\text { contaminated decedents. These guidelines are designed to } \\
\text { address both of these scenarios. They could also be applicable in } \\
\text { other instances where decedents' bodies are contaminated with } \\
\text { radioactive material (e.g., reactor accidents, transportation } \\
\text { accidents involving radioactive material, or the discharge of a } \\
\text { decedent from a hospital after injection or implantation of a } \\
\text { radiopharmaceutical). These guidelines suggest ways for } \\
\text { medical examiners, coroners, and morticians to deal with loose } \\
\text { surface contamination, internal contamination, or shrapnel on or } \\
\text { in decedents' bodies [CDC 2010g]. } \\
\text { Standard Type: N/A }\end{array}$ \\
\hline
\end{tabular}




\begin{tabular}{|c|c|}
\hline & $\begin{array}{l}\text { Organization: The Centers for Disease Control and Prevention } \\
\text { (CDC) } \\
\text { Classification: Operational guidelines }\end{array}$ \\
\hline $\begin{array}{l}\text { Health Insurance Portability and } \\
\text { Accountability Act (HIPAA) }\end{array}$ & $\begin{array}{l}\text { Description: The Health Insurance Portability and } \\
\text { Accountability Act (HIPAA) is a federal law that provides rights } \\
\text { and protections for participants and beneficiaries in group health } \\
\text { plans. HIPAA includes protections for coverage under group } \\
\text { health plans that limit exclusions for preexisting conditions; } \\
\text { prohibit discrimination against employees and dependents based } \\
\text { on their health status; and allow a special opportunity to enroll } \\
\text { in a new plan to individuals in certain circumstances [DOL } \\
\text { 2010]. The Administrative Simplification provisions of the } \\
\text { Health Insurance Portability and Accountability Act of } 1996 \\
\text { (HIPAA, Title II) required the Department of Health and Human } \\
\text { Services (HHS) to establish national standards for electronic } \\
\text { health care transactions and national identifiers for providers, } \\
\text { health plans, and employers. As the industry has implemented } \\
\text { these standards, and increased the use of electronic data } \\
\text { interchange, the nation’s health care system will become } \\
\text { increasingly effective and efficient [HHS 2010a]. } \\
\text { Standard Type: HIPAA of } 1996 \text { (P.L.104 - 191) } \\
\text { Organization: Department of Health and Human Services } \\
\text { (HHS) } \\
\text { Classification: Operational guidelines }\end{array}$ \\
\hline $\begin{array}{l}\text { Health Insurance Portability and } \\
\text { Accountability Act (HIPAA) Security } \\
\text { Rule }\end{array}$ & $\begin{array}{l}\text { Description: The HIPAA Security Rule establishes national } \\
\text { standards to protect individuals' electronic personal health } \\
\text { information that is created, received, used, or maintained by a } \\
\text { covered entity. The Security Rule requires appropriate } \\
\text { administrative, physical and technical safeguards to ensure the } \\
\text { confidentiality, integrity, and security of electronic protected } \\
\text { health information [HHS 2010b]. } \\
\text { Standard Type: HIPAA Security Rule } 164.308 \text { (a)(7)(i) } \\
\text { Organization: National Institute of Standards and Technology } \\
\text { (NIST) } \\
\text { Classification: Operational guidelines }\end{array}$ \\
\hline Health Level Seven (HL7) Standards & $\begin{array}{l}\text { Description: Health Level Seven is one of several American } \\
\text { National Standards Institute (ANSI) -accredited Standards } \\
\text { Developing Organizations (SDOs) operating in the healthcare } \\
\text { arena. Health Level Seven’s domain is clinical and } \\
\text { administrative data [HL7 2010]. HL7 standards are used for the } \\
\text { exchange, management, and integration of electronic healthcare } \\
\text { information. } \\
\text { Standard Type: ANSI/HL7 V2 XML-2003; ANSI/HL7 V2.5- } \\
\text { 2003; ANSI/HL7 V3 DSR, R1-2005, .... ANSI/HL7 V3 PM, } \\
\text { R1-2005; ANSI/HL7 V3 CR, R3-2005; ANSI/HL7 V3 MFRI, } \\
\text { R1-2006 } \\
\text { Organization: Health Level Seven (HL7); American National } \\
\text { Standards Institute (ANSI) }\end{array}$ \\
\hline
\end{tabular}




\begin{tabular}{|c|c|}
\hline & Classification: Domain-specific integration interfaces \\
\hline Infection Control & $\begin{array}{l}\text { Description: A plan that is used by the hospital to respond to an } \\
\text { influx, or the risk of an influx, of infectious patients } \\
\text { [JACHOSTD 2010]. } \\
\text { Standard Type: IC. } 6.10 \\
\text { Organization: The Joint Commission Resources } \\
\text { Classification: Operational guidelines }\end{array}$ \\
\hline $\begin{array}{l}\text { Interim Guidelines for Hospital } \\
\text { Response to Mass Casualties from a } \\
\text { Radiological Incident }\end{array}$ & $\begin{array}{l}\text { Description: The guidance focuses on six key areas: (1) } \\
\text { notification and communication, which emphasizes the } \\
\text { importance of hospitals working with their communities and } \\
\text { public health agencies on developing emergency communication } \\
\text { plans; (2) triage; (3) patient management, including } \\
\text { decontamination, treatment, care of special populations, } \\
\text { discharge and follow up, and patient mental health concerns; (4) } \\
\text { healthcare provider protection, including staff training and } \\
\text { practitioner mental health concerns; (5) surveillance, and (6) } \\
\text { community planning [CDC 2010h]. } \\
\text { Standard Type: N/A } \\
\text { Organization: the Centers for Disease Control and Prevention } \\
\text { (CDC) } \\
\text { Classification: Operational guidelines }\end{array}$ \\
\hline Interim Life Safety Meas & $\begin{array}{l}\text { Description: Guidelines for Design and Construction of } \\
\text { Hospital and Health Care Facilities to minimize the possibility } \\
\text { of injury or damage due to fire, smoke \& fumes, or other threat. } \\
\text { ILSM are health and safety measures that are put in place to } \\
\text { protect the safety of patients, visitors, and staff who work in the } \\
\text { hospital [BMET 2010]. } \\
\text { Standard Type: ILSM } \\
\text { Organization: The Joint Commission Resources } \\
\text { Classification: Operational guidelines }\end{array}$ \\
\hline $\begin{array}{l}\text { Interim Recommendations for } \\
\text { Firefighters \& Other First } \\
\text { Responders for the Selection \& Use } \\
\text { of Protective Clothing \& Respirators } \\
\text { Against Biological Agents }\end{array}$ & $\begin{array}{l}\text { Description: This interim statement of selection and use of } \\
\text { protective clothing and respirators against biological agents is } \\
\text { based on current understanding of the potential threats and } \\
\text { existing recommendations issued for biological aerosols. The } \\
\text { approach to any potentially hazardous atmosphere, including } \\
\text { biological hazards, must be made with a plan that includes an } \\
\text { assessment of hazard and exposure potential, respiratory } \\
\text { protection needs, entry conditions, exit routes, and } \\
\text { decontamination strategies [CDC 2010i]. } \\
\text { Standard Type: N/A } \\
\text { Organization: The Centers for Disease Control and Prevention } \\
\text { (CDC) } \\
\text { 6.3.2. Classification: Operational guidelines }\end{array}$ \\
\hline $\begin{array}{l}\text { International Classification of } \\
\text { Diseases }\end{array}$ & $\begin{array}{l}\text { Description: The International Classification of Diseases (ICD) } \\
\text { is designed to promote international comparability in the } \\
\text { collection, processing, classification, and presentation of }\end{array}$ \\
\hline
\end{tabular}




\begin{tabular}{|c|c|}
\hline & $\begin{array}{l}\text { mortality statistics. This includes providing a format for } \\
\text { reporting causes of death on the death certificate. The reported } \\
\text { conditions are then translated into medical codes through use of } \\
\text { the classification structure and the selection and modification } \\
\text { rules contained in the applicable revision of the ICD, published } \\
\text { by the World Health Organization. These coding rules improve } \\
\text { the usefulness of mortality statistics by giving preference to } \\
\text { certain categories, by consolidating conditions, and by } \\
\text { systematically selecting a single cause of death from a reported } \\
\text { sequence of conditions. The single selected cause for tabulation } \\
\text { is called the underlying cause of death, and the other reported } \\
\text { causes are the non-underlying causes of death. The combination } \\
\text { of underlying and non-underlying causes is the multiple causes } \\
\text { of death. The ICD has been revised periodically to incorporate } \\
\text { changes in the medical field. To date, there have been } 10 \\
\text { revisions of the ICD. [CDC 2010j]. } \\
\text { Standard Type: ICD-10; ICD-10-CM (ICD-10 Clinical } \\
\text { Modification) } \\
\text { Organization: The National Center for Health Statistics } \\
\text { (NCHS); Centers for Medicare and Medicaid Services } \\
\text { Classification: Operational guidelines }\end{array}$ \\
\hline $\begin{array}{l}\text { Introductory Resource Guide for } \\
\text { Implementing the Health Insurance } \\
\text { Portability and Accountability Act } \\
\text { (HIPAA) Security Rule }\end{array}$ & $\begin{array}{l}\text { Description: A publication discusses security considerations } \\
\text { and resources on security terms and concepts used and presented } \\
\text { in the HIPAA security rule [NIST 2010a]. } \\
\text { Standard Type: N/A } \\
\text { Organization: National Institute of Standards and Technology } \\
\text { (NIST) } \\
\text { Classification: Operational guidelines }\end{array}$ \\
\hline $\begin{array}{l}\text { Maintenance, Testing, and } \\
\text { Inspection Requirements for Hospital } \\
\text { Emergency Power System }\end{array}$ & $\begin{array}{l}\text { Description: A plan that identifies how a hospital maintains, } \\
\text { tests, and inspects its emergency power system [JCAHOSTD } \\
\text { 2010]. } \\
\text { Standard Type: EC.7.40 } \\
\text { Organization: The Joint Commission Resources } \\
\text { Classification: Operational guidelines }\end{array}$ \\
\hline $\begin{array}{l}\text { Managing Hazardous Material } \\
\text { Incidents (MHMI) }\end{array}$ & $\begin{array}{l}\text { Description: The MHMI series is a three volume set (with a } \\
\text { video) comprised of recommendations for on-scene (pre- } \\
\text { hospital), and hospital medical management of patients exposed } \\
\text { during a hazardous materials incident [CDC 2010k]. } \\
\text { Standard Type: N/A } \\
\text { Organization: The Agency for Toxic Substances and Disease } \\
\text { Registry (ATSDR) } \\
\text { Classification: Operational guidelines }\end{array}$ \\
\hline $\begin{array}{l}\text { Mass Casualty Event Preparedness } \\
\text { and Response }\end{array}$ & $\begin{array}{l}\text { Description: This document provides information of } \\
\text { preparedness and response for preparing for a terrorist bombing, } \\
\text { after a terrorist bombing, coping with a traumatic event, } \\
\text { emergency wound care, injuries, brain injuries, and burns, etc. }\end{array}$ \\
\hline
\end{tabular}




\begin{tabular}{|c|c|}
\hline & $\begin{array}{l}\text { [CDC 2010l]. } \\
\text { Standard Type: N/A } \\
\text { Organization: The Centers for Disease Control and Prevention } \\
\text { (CDC) } \\
\text { Classification: Operational guidelines }\end{array}$ \\
\hline $\begin{array}{l}\text { Medical Management Guidelines for } \\
\text { Unidentified Chemicals }\end{array}$ & $\begin{array}{l}\text { Description: Basic victim management recommendations to } \\
\text { follow when the chemical is not known [CDC 2010n]. } \\
\text { Standard Type: N/A } \\
\text { Organization: The Agency for Toxic Substances and Disease } \\
\text { Registry (ATSDR) } \\
\text { Classification: Operational guidelines }\end{array}$ \\
\hline $\begin{array}{l}\text { NIOSH Pocket Guide to Chemical } \\
\text { Hazards (NPG) }\end{array}$ & $\begin{array}{l}\text { Description: The NIOSH Pocket Guide to Chemical Hazards } \\
\text { (NPG) is intended as a source of general industrial hygiene } \\
\text { information on several hundred chemicals/classes for workers, } \\
\text { employers, and occupational health professionals. The NPG } \\
\text { does not contain an analysis of all pertinent data, rather it } \\
\text { presents key information and data in abbreviated or tabular form } \\
\text { for chemicals or substance groupings (e.g., cyanides, fluorides, } \\
\text { manganese compounds) that are found in the work environment. } \\
\text { The information found in the NPG should help users recognize } \\
\text { and control occupational chemical hazards [CDC 2010m]. } \\
\text { Standard Type: N/A } \\
\text { Organization: The National Institute for Occupational Safety \& } \\
\text { Health (NIOSH) } \\
\text { Classification: Operational guidelines }\end{array}$ \\
\hline Patient Flow Manc & $\begin{array}{l}\text { Description: Plans that identify and mitigate impediments to } \\
\text { efficient patient flow throughout the hospital [JCAHOSTD } \\
\text { 2010]. } \\
\text { Standard Type: LD.3.15 } \\
\text { Organization: The Joint Commission Resources } \\
\text { Classification: Operational guidelines }\end{array}$ \\
\hline $\begin{array}{l}\text { Population Monitoring in Radiation } \\
\text { Emergencies: A Guide for State and } \\
\text { Local Public Health Planners }\end{array}$ & $\begin{array}{l}\text { Description: This planners' guide presents an introduction to } \\
\text { population monitoring in radiation emergencies for public health } \\
\text { officials and emergency preparedness planners at the state and } \\
\text { local levels. It describes how to plan for population monitoring } \\
\text { and provides practical suggestions to address the many } \\
\text { challenges it presents when a large population is potentially } \\
\text { impacted. Population monitoring is the process of identifying, } \\
\text { screening, and monitoring people for exposure to radiation or } \\
\text { contamination from radioactive materials [CDC 2010o]. } \\
\text { Standard Type: N/A } \\
\text { Organization: The Centers for Disease Control and Prevention } \\
\text { (CDC) } \\
\text { Classification: Operational guidelines }\end{array}$ \\
\hline Preparing for a Terrorist Bomb & nis document focuses on common sense \\
\hline
\end{tabular}




\begin{tabular}{|c|c|}
\hline A Common Sense Approach & $\begin{array}{l}\text { principles that will be useful in a bombing event [CDC 2010p]. } \\
\text { Standard Type: N/A } \\
\text { Organization: The Centers for Disease Control and Prevention } \\
\text { (CDC) } \\
\text { Classification: Operational guidelines }\end{array}$ \\
\hline $\begin{array}{l}\text { Public Health Response to Biological } \\
\text { \& Chemical Terrorism: Interim } \\
\text { Planning Guidance for State Public } \\
\text { Health Officials }\end{array}$ & $\begin{array}{l}\text { Description: This Planning Guidance is designed to help state } \\
\text { public health officials determine the roles of their departments in } \\
\text { response to biological and chemical terrorism and to understand } \\
\text { the emergency response roles of local health departments and } \\
\text { the emergency management system. The Planning Guidance } \\
\text { also can be used to help state health departments coordinate their } \\
\text { efforts with the many agencies and organizations at all levels of } \\
\text { government that ultimately would respond to a biological or } \\
\text { chemical terrorism event [CDC 2010q]. } \\
\text { Standard Type: N/A } \\
\text { Organization: The Centers for Disease Control and Prevention } \\
\text { (CDC) } \\
\text { Classification: Operational guidelines }\end{array}$ \\
\hline $\begin{array}{l}\text { Recognition of Illness Associated } \\
\text { with the Intentional Release of a } \\
\text { Biologic Agent }\end{array}$ & $\begin{array}{l}\text { Description: The guidance provides healthcare providers \& } \\
\text { public health personnel for recognizing illnesses or patterns of } \\
\text { illness that might be associated with intentional release of } \\
\text { biologic agents [CDC 2010r]. } \\
\text { Standard Type: MMWR 2001 } \\
\text { Organization: The Centers for Disease Control and Prevention } \\
\text { (CDC) } \\
\text { Classification: Operational guidelines }\end{array}$ \\
\hline $\begin{array}{l}\text { Roundtable on Population } \\
\text { Monitoring Following a } \\
\text { Nuclear/Radiological Incident }\end{array}$ & $\begin{array}{l}\text { Description: Recommendations \& comments from participants } \\
\text { in CDC's roundtable (Jan. 11-12, 2005) on challenges associated } \\
\text { with monitoring people affected by a nuclear or radiological } \\
\text { incident [CDC 2010s]. } \\
\text { Standard Type: N/A } \\
\text { Organization: The Centers for Disease Control and Prevention } \\
\text { (CDC) } \\
\text { Classification: Operational guidelines }\end{array}$ \\
\hline $\begin{array}{l}\text { Sheltering in Place during a } \\
\text { Radiation Emergency }\end{array}$ & $\begin{array}{l}\text { Description: A fact sheet, prepared by the Centers for Disease } \\
\text { Control and Prevention, used during a radiation emergency to } \\
\text { help protect individuals and family and to help prepare a safe } \\
\text { and well-stocked shelter from exposure to radiation [CDC } \\
\text { 2010t]. } \\
\text { Standard Type: N/A } \\
\text { Organization: The Centers for Disease Control and Prevention } \\
\text { (CDC) } \\
\text { Classification: Operational guidelines }\end{array}$ \\
\hline Standard for Competence of & entifies the minimum levels of \\
\hline
\end{tabular}




\begin{tabular}{|c|c|}
\hline $\begin{array}{l}\text { Responders to Hazardous } \\
\text { Materials/Weapons of Mass } \\
\text { Destruction Incidents }\end{array}$ & $\begin{array}{l}\text { competence required by responders to emergencies involving } \\
\text { hazardous materials/weapons of mass destruction (WMD). It is } \\
\text { based on the operational philosophies that emergency } \\
\text { responders should be trained to perform their expected tasks, } \\
\text { and that a responder cannot safely and effectively respond to a } \\
\text { terrorism or criminal scenario involving hazmats/WMD if they } \\
\text { don’t first understand basic hazardous materials response } \\
\text { [NFPA 2010]. } \\
\text { Standard Type: NFPA 472-2008 } \\
\text { Organization: The National Fire Protection Association } \\
\text { (NFPA) } \\
\text { Classification: Operational guidelines }\end{array}$ \\
\hline $\begin{array}{l}\text { Standard for Competencies for EMS } \\
\text { Personnel Responding to Hazardous } \\
\text { Materials/Weapons of Mass } \\
\text { Destruction Incidents }\end{array}$ & $\begin{array}{l}\text { Description: The standard includes qualifications for EMS } \\
\text { responders to terrorism incidents that involve hazardous } \\
\text { materials. It identifies the levels of competence required of } \\
\text { emergency medical services (EMS) personnel who respond to } \\
\text { hazardous materials incidents. It specifically covers the } \\
\text { requirements for Basic Life Support (BLS) and Advanced Life } \\
\text { Support (ALS) personnel in the pre-hospital setting [NFPA } \\
\text { 2010]. } \\
\text { Standard Type: NFPA 473-2008 } \\
\text { Organization: The National Fire Protection Association } \\
\text { (NFPA) } \\
\text { Classification: Operational guidelines }\end{array}$ \\
\hline $\begin{array}{l}\text { Standard Guide for Assessing the } \\
\text { Health Hazard of Pesticides to } \\
\text { Applicators and Others with } \\
\text { Potential Exposure }\end{array}$ & $\begin{array}{l}\text { Description: This guide covers a stepwise process for using } \\
\text { information concerning biological, chemical, physical, and } \\
\text { toxicological properties of a pesticide or other chemical(s), or of } \\
\text { a formulation to identify adverse effects that may occur to } \\
\text { pesticide applicators or others with potential exposure [ASTM } \\
\text { 2011]. } \\
\text { Standard Type: E1429 - 91(2004) } \\
\text { Organization: ASTM International } \\
\text { Classification: Operational Guideline }\end{array}$ \\
\hline $\begin{array}{l}\text { Standard Guide for Hospital } \\
\text { Preparedness and Response }\end{array}$ & $\begin{array}{l}\text { Description: A guide intended to assist the leaders of hospitals } \\
\text { in the design, planning, and response to be undertaken by } \\
\text { hospitals and health care organizations to an event that } \\
\text { necessitates the activation of an emergency operations plan } \\
\text { [ASTM 2011]. } \\
\text { Standard Type: ASTM E2413 - } 04 \text { (2009) } \\
\text { Organization: ASTM International } \\
\text { Classification: Operational guidelines }\end{array}$ \\
\hline $\begin{array}{l}\text { Standard Practice for Radiological } \\
\text { Emergency Response }\end{array}$ & $\begin{array}{l}\text { Description: This practice provides decision-making } \\
\text { considerations for response to incidents that involve radioactive } \\
\text { materials. It provides information and guidance for what to } \\
\text { include in response planning, and what activities to conduct } \\
\text { during a response. It should be used in emergency services }\end{array}$ \\
\hline
\end{tabular}




\begin{tabular}{|l|l|}
\hline & $\begin{array}{l}\text { response such as law enforcement, fire department, and } \\
\text { emergency medical response actions. This practice assumes that } \\
\text { implementation begins with the recognition of a radiological } \\
\text { incident and ends when emergency response actions cease or the } \\
\text { response is assumed by specialized regional, state, or federal } \\
\text { response teams [ASTM 2011]. } \\
\text { Standard Type: ASTM E2601-08 } \\
\text { Organization: ASTM International } \\
\text { Classification: Operational guidelines }\end{array}$ \\
\hline
\end{tabular}

\subsubsection{Conceptual Modeling Standards}

\begin{tabular}{|c|c|}
\hline Standard Title & Overview \\
\hline $\begin{array}{l}\text { Discrete Event System Specification } \\
\text { (DEVS) }\end{array}$ & $\begin{array}{l}\text { Description: DEVS is a systems-theoretic approach to } \\
\text { modeling. More specifically, it is state-centered formalism. A } \\
\text { system consists of interconnected subsystems. A subsystem is a } \\
\text { system. Leaf systems (atomic DEVSes) are state machines. } \\
\text { DEVS can be viewed as a framework unifying a number of } \\
\text { other formalisms in a consistent, systems theoretic, state } \\
\text { centered fashion [DEVS 2011]. } \\
\text { Standard Type: Specification } \\
\text { Organization: Simulation Interoperability Standards } \\
\text { Organization (SISO); Society for Modeling and Computer } \\
\text { Simulation International (SCS) } \\
\text { Classification: Domain-specific integration interface }\end{array}$ \\
\hline $\begin{array}{l}\text { Systems Modeling Language } \\
(\text { SysML) }\end{array}$ & $\begin{array}{l}\text { Description: SysML is a general purpose modeling language for } \\
\text { systems engineering applications. It is a dialect of UML, the } \\
\text { industry standard for modeling software-intensive systems. It } \\
\text { supports the specification, analysis, design, verification and } \\
\text { validation of a broad range of systems and systems-of-systems. } \\
\text { These systems may include hardware, software, information, } \\
\text { processes, personnel, and facilities [OMG 2011]. } \\
\text { Standard Type: SysML } 1.2 \\
\text { Organization: Object Management Group, Inc. (OMG) } \\
\text { Classification: Document format }\end{array}$ \\
\hline Unified Modeling Language (UML) & $\begin{array}{l}\text { Description: A graphical language for visualizing, specifying, } \\
\text { constructing and documenting the artifacts of a software- } \\
\text { intensive system. The UML offers a standard way to write a } \\
\text { system's blueprints, including conceptual things such as } \\
\text { business processes and system functions, as well as concrete } \\
\text { things such as programming language statements, database } \\
\text { schemas, and reusable software components [ANSI 2011c]. } \\
\text { Standard Type: UML 2.0, UML 2.1.1; UML 2.1.2; UML 2.2; } \\
\text { UML 2.3; ISO/IEC 19501:2004 } \\
\text { Organization: ISO; ANSI; Object Management Group, Inc. } \\
\text { (OMG) }\end{array}$ \\
\hline
\end{tabular}




\subsubsection{Distributed Simulation Standards}

\begin{tabular}{|c|c|}
\hline Standard Title & Overview \\
\hline Distributed Interactive Simulation & $\begin{array}{l}\text { Description: Distributed Interactive Simulation (DIS) is a } \\
\text { government/industry initiative to define an infrastructure for } \\
\text { linking simulations of various types at multiple locations to } \\
\text { create realistic, complex, virtual worlds for the simulation of } \\
\text { highly interactive activities. A series of IEEE standards to } \\
\text { support information exchange between simulation applications } \\
\text { participating in the DIS environment are defined. IEEE Std } \\
1278.1 \text { defines the format and semantics of data messages, also } \\
\text { known as Protocol Data Units (PDUs), that are exchanged } \\
\text { between simulation applications and simulation management. } \\
\text { IEEE Std 1278.2 defines the communication services required to } \\
\text { support the message exchange described in IEEE Std 1278.1. } \\
\text { IEEE 1278-3 provides guidelines for establishing a DIS } \\
\text { exercise, managing the exercise, and providing proper feedback. } \\
\text { IEEE 1278-4 establishes guidelines for the verification, } \\
\text { validation, and accreditation (VV\&A) of Distributed Interactive } \\
\text { Simulation (DIS) exercises [IHS 2011a]. } \\
\text { Standard Type: IEEE 1278-1993, IEEE 1278.1-1995, IEEE } \\
\text { 1278.1A-1998, IEEE-1278.2-1995, IEEE 1278.3-1996, IEEE } \\
\text { 1278.4-1997 } \\
\text { Organization: IEEE; IHS, Inc. } \\
\text { Classification: Domain-specific integration interface }\end{array}$ \\
\hline $\begin{array}{l}\text { Extensible Modeling and Simulation } \\
\text { Framework }(X M S F)\end{array}$ & $\begin{array}{l}\text { Description: The Extensible Modeling and Simulation } \\
\text { Framework (XMSF) is defined as a set of Web-based } \\
\text { technologies and services, applied within an extensible } \\
\text { framework, that enables a new generation of modeling \& } \\
\text { simulation (M\&S) applications to emerge, develop and } \\
\text { interoperate [DODCCRP 2011]. XMSF provides a framework } \\
\text { which allows both Department of Defense (DoD) and non-DoD } \\
\text { Modeling and Simulation (M\&S) projects to take advantage of } \\
\text { Web-based technologies. } \\
\text { Standard Type: XMSF } 1.0 \\
\text { Organization: Naval Postgraduate School MOVES Institute; } \\
\text { George Mason University NetLab; Science Applications } \\
\text { International Corporation; Old Dominion University } \\
\text { Classification: Domain-specific integration interface }\end{array}$ \\
\hline High Level Architecture (HLA) & $\begin{array}{l}\text { Description: This standard defines the HLA, its components, } \\
\text { and the rules that outline the responsibilities of HLA federates } \\
\text { and federations to ensure a consistent implementation [IEEE } \\
\text { 2011c]. } \\
\text { Standard Type: IEEE 1516-2000, IEEE 1516.1-2000, 1516.2- }\end{array}$ \\
\hline
\end{tabular}


2000, ANSI/IEEE 1516.3-2003; IEEE 1516.4-2007

Organization: IEEE/Simulation Interoperability Standards

Organization (SISO); ANSI

Classification: Domain-specific integration interface

\subsubsection{Selected Geographic Information System (GIS) Standards}

\begin{tabular}{|c|c|}
\hline Standard Title & Overview \\
\hline $\begin{array}{l}\text { CityGML - Exchange and Storage of } \\
\text { Virtual 3D City Models }\end{array}$ & $\begin{array}{l}\text { Description: A standard for the representation, storage, and } \\
\text { exchange of virtual 3D city and landscape models. CityGML is } \\
\text { implemented as an application schema of the Geography } \\
\text { Markup Language version 3.1.1. It is based on a rich, general } \\
\text { purpose information model in additional to geometry and } \\
\text { appearance information. For specific domain areas, CityGML } \\
\text { also provides an extension mechanism to enrich the data with } \\
\text { identifiable features under preservation of semantic } \\
\text { interoperability [OGC 2011a]. } \\
\text { Standard Type: OGC 06-057r1; ISO TC211 } \\
\text { Organization: Open Geospatial Consortium, Inc. (OGC) } \\
\text { Classification: Domain-specific integration interface }\end{array}$ \\
\hline $\begin{array}{l}\text { American National Standard for } \\
\text { Information Technology - } \\
\text { Geographical Information Systems - } \\
\text { Spatial Data Standard for Facilities, } \\
\text { Infrastructure, and Environment } \\
\text { (SDSFIE) }\end{array}$ & $\begin{array}{l}\text { Description: This standard provides a means to model and } \\
\text { categorize real-world geographic phenomena of interest to the } \\
\text { Facilities, Infrastructure, and Environment (FIE) Domain(s) into } \\
\text { a set of geographic data that can be represented in a spatial } \\
\text { database and presented to a user in digital form. This SDSFIE } \\
\text { standard is intended to provide the enterprise spatial database } \\
\text { schema to support multiple FIE applications. This National } \\
\text { Standard is applicable to the federal, state, county, and city } \\
\text { agencies; private companies; and any other organizations that } \\
\text { perform AM \& FM functions for facilities and other types of } \\
\text { infrastructure (such as roads, waterways, utility systems, etc,) } \\
\text { and/or perform environmental compliance, restoration, and/or } \\
\text { pollution prevention activities [ANSI 2011a]. } \\
\text { Standard Type: ANSI INCITS 353-2006 } \\
\text { Organization: American National Standards Institute (ANSI); } \\
\text { International Committee for Information Technology Standards } \\
\text { (INCITS) } \\
\text { Classification: Domain-specific integration interface }\end{array}$ \\
\hline $\begin{array}{l}\text { Content Standard for Digital } \\
\text { Geospatial Metadata (CSDGM) }\end{array}$ & $\begin{array}{l}\text { Description: The standard is often referred to as the FGDC } \\
\text { Metadata Standard. The objectives of the standard are to } \\
\text { provide a common set of terminology and definitions for the } \\
\text { documentation of digital geospatial data. The standard } \\
\text { establishes the names of data elements and compound elements } \\
\text { (groups of data elements) to be used for these purposes, the } \\
\text { definitions of these compound elements and data elements, and } \\
\text { information about the values that are to be provided for the data }\end{array}$ \\
\hline
\end{tabular}




\begin{tabular}{|c|c|}
\hline & $\begin{array}{l}\text { elements [FGDC 2011a]. } \\
\text { Standard Type: FGDC-STD-001-1998; FGDC-STD-001.1- } \\
\text { 1999; FGDC-STD-001.2-2001 } \\
\text { Organization: Federal Geographic Data Committee (FGDC) } \\
\text { Classification: Domain-specific integration interface }\end{array}$ \\
\hline $\begin{array}{l}\text { Content Standard for Digital } \\
\text { Geospatial Metadata (CSDGM) - } \\
\text { Extensions for Remote Sensing } \\
\text { Metadata }\end{array}$ & $\begin{array}{l}\text { Description: The standard of Extensions for Remote Sensing } \\
\text { Metadata standard provides a common terminology and set of } \\
\text { definitions for documenting geospatial data obtained from } \\
\text { remote sensing, within the framework of the FGDC Content } \\
\text { Standard for Digital Geospatial Metadata (CSDGM) standard. } \\
\text { The extensions provide a means to use standard FGDC content } \\
\text { to describe geospatial data derived from remote sensing } \\
\text { measurements. This standard is intended to support the } \\
\text { collection and processing of geospatial metadata for data derived } \\
\text { from remote sensing. It is intended to be used by all levels of } \\
\text { government and the private sector [FGDC 2011b]. } \\
\text { Standard Type: FGDC-STD-012-2002 } \\
\text { Organization: The Federal Geographic Data Committee } \\
\text { (FGDC) } \\
\text { Classification: Domain-specific integration interface }\end{array}$ \\
\hline GeoAPI SWG Standard & $\begin{array}{l}\text { Description: The GeoAPI Standard Working Group (SWG) } \\
\text { aims to create the GeoAPI 3.0 Standard, which will define a set } \\
\text { of Java language interfaces along with an associated test suite, to } \\
\text { provide a standardized, programming language level realization } \\
\text { of some core Open Geospatial Consortium (OGC) } \\
\text { specifications. These interfaces will facilitate the creation of } \\
\text { accurate, coherent, interoperable, and verifiable implementations } \\
\text { of those OGC standards [GEOAPI 2011]. } \\
\text { Standard Type: OGC GeoAPI 3.0 SWG } \\
\text { Organization: OGC } \\
\text { Classification: Domain-specific integration interface }\end{array}$ \\
\hline Geographic Information - Encoding & $\begin{array}{l}\text { Description: The standard specifies the requirements for } \\
\text { defining encoding rules to be used for interchange of geographic } \\
\text { data within the ISO } 19100 \text { series of International Standards [ISO } \\
\text { 2011b]. } \\
\text { Standard Type: ISO 19118:2005 } \\
\text { Organization: ISO } \\
\text { Classification: Domain-specific integration interface }\end{array}$ \\
\hline $\begin{array}{l}\text { Geographic Information - Location- } \\
\text { Based services - Multimodal Routing } \\
\text { and Navigation }\end{array}$ & $\begin{array}{l}\text { Description: The standard specifies the data types and their } \\
\text { associated operations for the implementation of multimodal } \\
\text { location-based services for routing and navigation. It is designed } \\
\text { to specify web services that may be made available to wireless } \\
\text { devices through web-resident proxy applications, but is not } \\
\text { limited to that environment [ISO 2011b]. } \\
\text { Standard Type: ISO 19134:2007 } \\
\text { Organization: ISO }\end{array}$ \\
\hline
\end{tabular}




\begin{tabular}{|c|c|}
\hline & Classification: Domain-specific integration interface \\
\hline $\begin{array}{l}\text { Geographic Information - Location- } \\
\text { based Services - Tracking and } \\
\text { Navigation }\end{array}$ & $\begin{array}{l}\text { Description: ISO } 19133: 2005 \text { describes the data types, and } \\
\text { operations associated with those types, for the implementation } \\
\text { of tracking and navigation services. It is designed to specify web } \\
\text { services that can be made available to wireless devices through } \\
\text { web-resident proxy applications, but is not restricted to that } \\
\text { environment [ISO 2011b]. } \\
\text { Standard Type: ISO 19133:2005 } \\
\text { Organization: ISO } \\
\text { Classification: Domain-specific integration interface }\end{array}$ \\
\hline Geographic Information - Portrayal & $\begin{array}{l}\text { Description: The standard defines a schema describing the } \\
\text { portrayal of geographic information in a form understandable by } \\
\text { humans. It includes the methodology for describing symbols and } \\
\text { mapping of the schema to an application schema. It does not } \\
\text { include standardization of cartographic symbols, and their } \\
\text { geometric and functional description [ISO 2011b]. } \\
\text { Standard Type: ISO 19117:2005 } \\
\text { Organization: ISO } \\
\text { Classification: Domain-specific integration interface }\end{array}$ \\
\hline $\begin{array}{l}\text { Geographic Information - } \\
\text { Procedures for Item Registration }\end{array}$ & $\begin{array}{l}\text { Description: ISO 19135:2005 specifies procedures to be } \\
\text { followed in establishing, maintaining and publishing registers of } \\
\text { unique, unambiguous and permanent identifiers, and meanings } \\
\text { that are assigned to items of geographic information. In order to } \\
\text { accomplish this purpose, ISO 19135:2005 specifies elements of } \\
\text { information that are necessary to provide identification and } \\
\text { meaning to the registered items and to manage the registration of } \\
\text { these items [ISO 2011b]. } \\
\text { Standard Type: INCITS/ISO/IEC 19135-2005 } \\
\text { Organization: ISO; International Committee for Information } \\
\text { Technology Standards (INCITS); International Electrotechnical } \\
\text { Commission (IEC) } \\
\text { Classification: Domain-specific integration interface }\end{array}$ \\
\hline $\begin{array}{l}\text { Geographic Information - Schema } \\
\text { for Moving Features }\end{array}$ & $\begin{array}{l}\text { Description: The standard defines a method to describe the } \\
\text { geometry of a feature that moves as a rigid body [ISO 2011b]. } \\
\text { Standard Type: ISO 19141:2008 } \\
\text { Organization: ISO } \\
\text { Classification: Domain-specific integration interface }\end{array}$ \\
\hline Geographic Information - Services & $\begin{array}{l}\text { Description: ISO 19119:2005 identifies and defines the } \\
\text { architecture patterns for service interfaces used for geographic } \\
\text { information, defines its relationship to the Open Systems } \\
\text { Environment model, presents a geographic services taxonomy } \\
\text { and a list of example geographic services placed in the services } \\
\text { taxonomy. It also prescribes how to create a platform-neutral } \\
\text { service specification, how to derive conformant platform- } \\
\text { specific service specifications, and provides guidelines for the }\end{array}$ \\
\hline
\end{tabular}




\begin{tabular}{|c|c|}
\hline & $\begin{array}{l}\text { selection and specification of geographic services from both } \\
\text { platform-neutral and platform-specific perspectives [ISO } \\
\text { 2011b]. } \\
\text { Standard Type: INCITS/ISO 19119-2005 } \\
\text { Organization: ISO; International Committee for Information } \\
\text { Technology Standards (INCITS) } \\
\text { Classification: Domain-specific integration interface }\end{array}$ \\
\hline $\begin{array}{l}\text { Geographic Information - Simple } \\
\text { Feature Access }\end{array}$ & $\begin{array}{l}\text { Description: ISO 19125-1:2004 establishes a common } \\
\text { architecture for geographic information and defines terms to use } \\
\text { within the architecture. It also standardizes names and geometric } \\
\text { definitions for Types for Geometry. INCITS/ISO 19125-2-2004 } \\
\text { specifies an Structured Query Language (SQL) schema that } \\
\text { supports storage, retrieval, query and update of simple } \\
\text { geospatial feature collections via the SQL Call Level Interface } \\
\text { (SQL/CLI) and establishes an architecture for the } \\
\text { implementation of feature tables. INCITS/ISO 19125-2-2004 } \\
\text { defines terms to use within the architecture of geographic } \\
\text { information and defines a simple feature profile of ISO 19107. } \\
\text { In addition, this part of ISO 19125:2004 describes a set of SQL } \\
\text { Geometry Types together with SQL functions on those types. } \\
\text { The Geometry Types and Functions described represent a profile } \\
\text { of ISO 13249-3. INCITS/ISO 19125-2-2004 standardizes the } \\
\text { names and geometric definitions of the SQL Types for } \\
\text { Geometry and the names, signatures and geometric definitions } \\
\text { of the SQL Functions for Geometry [ISO 2011b]. } \\
\text { Standard Type : INCITS/ISO 19125-1-2004 ; INCITS/ISO } \\
\text { 19125-2-2004 } \\
\text { Organization: ISO; International Committee for Information } \\
\text { Technology Standards (INCITS) } \\
\text { Classification: Domain-specific integration interface }\end{array}$ \\
\hline $\begin{array}{l}\text { Geographic Information Framework } \\
\text { Data Standard }\end{array}$ & $\begin{array}{l}\text { Description: The standard establishes common data } \\
\text { requirements for the exchange of National Spatial Data } \\
\text { Infrastructure (NSDI) framework data [FGDC 2011c]. } \\
\text { Standard Type: FGDC-STD-014.0-2008; FGDC-STD-014.1- } \\
\text { 2008; FGDC-STD-014.2-2008; FGDC-STD-014.3-2008; } \\
\text { FGDC-STD-014.4-2008; FGDC-STD-014.5-2008; FGDC-STD- } \\
\text { 014.6-2008; FGDC-STD-014.7-2008; FGDC-STD-014.7b- } \\
\text { 2008; FGDC-STD-014.7c-2008; FGDC-STD-014.7d-2008; } \\
\text { FGDC-STD-014.7e-2008 } \\
\text { Organization: Federal Geographic Data Committee (FGDC) } \\
\text { Classification: Domain-specific integration interface }\end{array}$ \\
\hline GeoTIFF & $\begin{array}{l}\text { Description: GeoTIFF is a metadata format, which provides } \\
\text { geographic information to associate with the image data. } \\
\text { GeoTIFF implements the geographic metadata formally, using } \\
\text { compliant Tagged Image File (TIFF 6.0) tags and structures. } \\
\text { "GeoTIFF" refers to TIFF files, which have geographic (or } \\
\text { cartographic) data embedded as tags within the TIFF file. The } \\
\text { geographic data can then be used to position the image in the }\end{array}$ \\
\hline
\end{tabular}




\begin{tabular}{|c|c|}
\hline & $\begin{array}{l}\text { correct location and geometry on the screen of a geographic } \\
\text { information display [GEOTIFF 2011]. } \\
\text { Standard Type: GeoTIFF/Revision } 1.0 \\
\text { Organization: geotiff.osgeo.org } \\
\text { Classification : Document format }\end{array}$ \\
\hline $\begin{array}{l}\text { Governmental Unit and Other } \\
\text { Geographic Area Boundaries }\end{array}$ & $\begin{array}{l}\text { Description: A specification for establishing of content } \\
\text { requirements for the collection and interchange of Government } \\
\text { units and legal entity boundary data and for facilitating the } \\
\text { maintenance and use of that information [FGDC 2010]. } \\
\text { Standard Type: FGDC-STD-014.5-2008 } \\
\text { Organization: Federal Geographic Data Committee (FGDC) } \\
\text { Classification: Domain-specific Integration Interfaces }\end{array}$ \\
\hline GRIdded Binary (GRIB) & $\begin{array}{l}\text { Description: Format specifications for representing } \\
\text { meteorological, gridded-point data [WMO 2010a]. } \\
\text { Standard Type: FM 92-IX Ext. GRIB; FM 92-VIII EXT. GRIB } \\
\text { Organization: World Meteorological Organization (WMO) } \\
\text { Classification: Domain-specific Integration Interfaces }\end{array}$ \\
\hline $\begin{array}{l}\text { Homeland Security Mapping } \\
\text { Standard - Point Symbology for } \\
\text { Emergency Management }\end{array}$ & $\begin{array}{l}\text { Description: The primary purpose of this standard is to } \\
\text { establish a common set of symbols for use by mapmakers in } \\
\text { support of emergency managers and first responders. It will } \\
\text { allow users to rapidly interpret map data and to be able to } \\
\text { disseminate consistent, usable information. This American } \\
\text { National Standard is applicable to all organizations that create } \\
\text { maps or otherwise display features for the Emergency } \\
\text { Management or First Responder communities. It is limited at } \\
\text { this time to support portrayal of point features that relate to the } \\
\text { emergency management and hazard mapping disciplines [ANSI } \\
\text { 2011b]. } \\
\text { Standard Type: ANSI INCITS } 415-2006 \\
\text { Organization: American National Standards Institute (ANSI); } \\
\text { International Committee for Information Technology Standards } \\
\text { (INCITS) } \\
\text { Classification: Domain-specific integration interface }\end{array}$ \\
\hline $\begin{array}{l}\text { OpenGIS Implementation } \\
\text { Specification for Geographic } \\
\text { Information - Simple Feature Access }\end{array}$ & $\begin{array}{l}\text { Description: The OpenGIS Simple Features Interface Standard } \\
\text { (SFS) provides a well-defined and common way for applications } \\
\text { to store and access feature data in relational or object-relational } \\
\text { databases, so that the data can be used to support other } \\
\text { applications through a common feature model, data store, and } \\
\text { information access interface. OpenGIS Simple Features are } \\
\text { geospatial features described using vector data elements such as } \\
\text { points, lines, and polygons [OGC 2011c]. } \\
\text { Standard Type: OGC 06-103r4 Version 1.2.1, OGC 05-126 } \\
\text { Organization: Open Geospatial Consortium, Inc (OGC) } \\
\text { Classification: Domain-specific integration interface }\end{array}$ \\
\hline Spatial Data Transfer Standar & ion: The Spatial Data Transfer Standard (SDTS) base \\
\hline
\end{tabular}




\begin{tabular}{|l|l|}
\hline (SDTS) & $\begin{array}{l}\text { specification (Parts 1, 2, and 3) describes the underlying } \\
\text { conceptual model and the detailed specifications for the content, } \\
\text { structure, and format for exchange of spatial data. Additional } \\
\text { parts (4, 5, 6, and potentially others) are added as profiles, each } \\
\text { of which defines specific rules and formats for applying SDTS } \\
\text { for the exchange of particular types of data [FGDC 2011d] } \\
\text { Standard Type: FGDC-STD-002.1; FGDC-STD-002.5; FGDC- } \\
\text { STD-002.6; FGDC-STD-002.7-2000 } \\
\text { Organization: Federal Geographic Data Committee (FGDC) } \\
\text { Classification: Domain-specific integration interface }\end{array}$ \\
\hline $\begin{array}{ll}\text { Standard for a U.S. National Grid } \\
\text { (USNG) }\end{array}$ & $\begin{array}{l}\text { Description: A standard is used to define the U.S. National Grid } \\
\text { and supports Universal Transverse Mercator (UTM) } \\
\text { coordinates, Military Grid Reference System (MGRS) grids, and } \\
\text { the specific grid presentation requirements. It is used for } \\
\text { acquisition/production of printed map and acquisition of } \\
\text { location service appliances with printed map products [FGDC } \\
\text { 2011e] } \\
\text { Standard Type: FGDC-STD-011-2001 } \\
\text { Organization: Federal Geographic Data Committee (FGDC) } \\
\text { Classification: Domain-specific integration interface }\end{array}$ \\
\hline
\end{tabular}

\subsubsection{Selected Communication Standards}

\begin{tabular}{|l|l|}
\hline \multicolumn{1}{|c|}{ Standard Title } & \multicolumn{1}{|c|}{ Overview } \\
\hline Common Alerting Protocol (CAP) & $\begin{array}{l}\text { Description: The Common Alerting Protocol (CAP) is a simple, } \\
\text { flexible data interchange format for collecting and distributing } \\
\text { "all-hazard" safety notifications and emergency warnings over } \\
\text { information networks and public alerting systems. In Web- } \\
\text { services applications, CAP provides a lightweight standard for } \\
\text { exchanging urgent notifications. CAP can also be used in data- } \\
\text { broadcast applications and over legacy data networks. CAP is } \\
\text { fully compatible with the existing national broadcast Emergency }\end{array}$ \\
$\begin{array}{ll}\text { Alert System (EAS) [OASIS 2011a]. It is an XML-related data } \\
\text { interchange standard for alerting and event notification } \\
\text { applications. The standard supports two functions: a standalone } \\
\text { protocol and a payload for Emergency Data Exchange Language } \\
\text { (EDXL) messages. } \\
\text { Standard Type: CAP-V1.1 } \\
\text { Organization: Organization for the Advancement of Structured } \\
\text { Information Standards (OASIS) } \\
\text { Classification: Domain-specific integration interface }\end{array}$ \\
\hline $\begin{array}{l}\text { Common Incident Management } \\
\text { Message Sets for use by Emergency }\end{array}$ & $\begin{array}{l}\text { Description: This standard is the Base Standard for a family of } \\
\text { related standards that address the intercommunication needs of } \\
\text { emergency management centers and other types of centers } \\
\text { engaged in transportation incident management [IEEE 2010]. } \\
\text { Standard Type: IEEE 1512-2000, IEEE 1512.1, IEEE 1512.2, }\end{array}$ \\
\hline
\end{tabular}




\begin{tabular}{|l|l|}
\hline & $\begin{array}{l}\text { IEEE 1512.3 } \\
\text { Organization: Institute of Electrical and Electronics Engineers } \\
\text { (IEEE) } \\
\text { Classification: Document Format }\end{array}$ \\
\hline $\begin{array}{l}\text { Emergency Data Exchange } \\
\text { Language (EDXL) }\end{array}$ & $\begin{array}{l}\text { Description: Several organizations are collaborating on the } \\
\text { design and development of a suite of specifications under the } \\
\text { name "Emergency Data Exchange Language (EDXL)" [OASIS } \\
\text { 2011b]. EDXL is an integrated framework for a wide range of } \\
\text { emergency data exchange standards to support operations, } \\
\text { logistics, planning, and finance. } \\
\text { Standard Type: EXDL Distribution Element, V. 1.0 (EDXL- } \\
\text { DE-V1.0); EDXL Resource Message Specification 1.0 Working } \\
\text { Draft Version 26 (EDXL-RM 1.0 v0026); EDXL Hospital } \\
\text { Availability Exchange v1.0 Public Review Draft 02 (EDXL- } \\
\text { HAVE-1.0-spec-pr02) } \\
\text { Organization: Organization for the Advancement of Structured } \\
\text { Information Standards (OASIS); Department of Homeland } \\
\text { Security (DHS); Emergency Interoperability Consortium (EIC) } \\
\text { Classification: Domain-specific integration interface }\end{array}$ \\
\hline $\begin{array}{l}\text { National Information Exchange } \\
\text { Model (NIEM) }\end{array}$ & $\begin{array}{l}\text { Description: NIEM is designed to develop, disseminate, and } \\
\text { support enterprise-wide information exchange standards and } \\
\text { processes that can enable jurisdictions to effectively share } \\
\text { critical information in emergency situations, as well as support } \\
\text { the day-to-day operations of agencies throughout the nation } \\
\text { [NIEM 2011]. } \\
\text { Organization: A partnership of the U.S. Department of Justice, } \\
\text { the U.S. Department of Homeland Security, and the U.S. } \\
\text { Department of Health and Human Services. } \\
\text { Classification: Domain-specific integration interface }\end{array}$ \\
\hline
\end{tabular}

\subsection{Data Sources}

This section identifies databases and other sources of data that may be used to develop or run healthcare models and simulations. The name of data source, a brief description of its contents, its access location, responsible organization, data formats used, as well as classification of the type of data is given below.

\begin{tabular}{|l|l|}
\hline \multicolumn{1}{|c|}{ Data Source Title } & \multicolumn{1}{|c|}{ Overview } \\
\hline Ambulatory Health Care Data & $\begin{array}{l}\text { Description: The National Ambulatory Medical Care Survey } \\
\text { (NAMCS) is a national survey designed to meet the need for } \\
\text { objective, reliable information about the provision and use of } \\
\text { ambulatory medical care services in the United States. Findings } \\
\text { are based on a sample of visits to non-federal employed office- } \\
\text { based physicians who are primarily engaged in direct patient } \\
\text { care. The National Hospital Ambulatory Medical Care Survey } \\
\text { (NHAMCS) is designed to collect data on the utilization and } \\
\text { provision of ambulatory care services in hospital emergency and }\end{array}$ \\
\hline
\end{tabular}




\begin{tabular}{|c|c|}
\hline & $\begin{array}{l}\text { outpatient departments. Findings are based on a national sample } \\
\text { of visits to the emergency departments and outpatient } \\
\text { departments of non-institutional general and short-stay hospitals } \\
\text { [CDC 2010y]. } \\
\text { Data Source: NAMCS/NHAMCS } \\
\text { Organization: National Center for Health Statistics (NCHS) of } \\
\text { the Centers for Disease Control and Prevention (CDC) } \\
\text { Format: Report } \\
\text { Classification: Demographic and Behavior, Resources }\end{array}$ \\
\hline $\begin{array}{l}\text { American Hospital Association } \\
\text { (AHA) Database }\end{array}$ & $\begin{array}{l}\text { Description: American Hospital Association (AHA) Database } \\
\text { contains data for every hospital in the U.S. The data is collected } \\
\text { from AHA annually survey. Non-responding hospital data are } \\
\text { estimated using advanced methods to approximate specific data } \\
\text { elements. Multiple data sets power this database, including the } \\
\text { latest edition of the AHA Annual Survey of Hospitals, primary } \\
\text { research into the organizational structures of Systems and } \\
\text { Networks conducted by Health Forum, and information from } \\
\text { Health Forum subscriber lists [AHADATA 2010a]. } \\
\text { Data Source: American Hospital Association (AHA) Database. } \\
\text { Five tools are provided: Hospital Statistics Wizard; Hospital } \\
\text { Market Analysis Wizard; Health Care Systems and Networks } \\
\text { Wizard; Hospital Detail Report Wizard; Mailing List Wizard } \\
\text { Organization: American Hospital Association (AHA) } \\
\text { Format Used: PDF, Excel table, Chart } \\
\text { Classification: Resources, Demographic and Behavior }\end{array}$ \\
\hline American Housing Surv & $\begin{array}{l}\text { Description: The American Housing Survey (AHS) collects data } \\
\text { on the Nation's housing, including apartments, single-family } \\
\text { homes, mobile homes, vacant housing units, household } \\
\text { characteristics, income, housing and neighborhood quality, } \\
\text { housing costs, equipment and fuels, size of housing unit, and } \\
\text { recent movers. National data are collected in odd numbered } \\
\text { years, and data for each of } 47 \text { selected Metropolitan Areas are } \\
\text { collected currently about every six years. The national sample } \\
\text { covers an average 55,000 housing units. Each metropolitan area } \\
\text { sample covers 4,100 or more housing units. The Data Access } \\
\text { includes three categories: National Data, Metropolitan Data, and } \\
\text { Dates metropolitan Areas are Survey [CENSUS 2010]. } \\
\text { Data Source: AHS Data Access } \\
\text { Organization: U.S. Census Bureau (USCS) } \\
\text { Format Used: Excel; PDF } \\
\text { Classification: Demographic and Behavioral }\end{array}$ \\
\hline $\begin{array}{l}\text { Behavioral Risk Factor Surveillance } \\
\text { System (BRFSS) }\end{array}$ & $\begin{array}{l}\text { Description: The Behavioral Risk Factor Surveillance System } \\
\text { (BRFSS) is a state-based system of health surveys that collects } \\
\text { information on health risk behaviors, preventive health practices, } \\
\text { and health care access primarily related to chronic disease and } \\
\text { injury. For many states, the BRFSS is the only available source of } \\
\text { timely, accurate data on health-related behaviors [CDC 2010u]. } \\
\text { Data Source: BRFSS Maps, BRFSS GIS Data, BRFSS Datasets }\end{array}$ \\
\hline
\end{tabular}




\begin{tabular}{|c|c|}
\hline & $\begin{array}{l}\text { Organization: Centers for Disease Control and Prevention, } \\
\text { National Center for Chronic Disease Prevention and Health } \\
\text { Promotion/Division of Adult and Community Health } \\
\text { Format: SHP, RTF, SAS, XPT, PDF, TXT, CSV, SAS7BCAT, } \\
\text { SAS7BDAT, ZIP } \\
\text { Classification: Demographic and Behavior, Controlling } \\
\text { Documents, Incidents }\end{array}$ \\
\hline $\begin{array}{l}\text { CDC Wide-ranging Online Data for } \\
\text { Epidemiologic Research } \\
\text { (WONDER) }\end{array}$ & $\begin{array}{l}\text { Description: The Centers for Disease Control and Prevention } \\
\text { (CDC) WONDER - Wide-ranging Online Data for } \\
\text { Epidemiologic Research - is an integrated information and } \\
\text { communication system for public health. It speeds and simplifies } \\
\text { access to public health information for state and local health } \\
\text { departments, the public health service, and the academic public } \\
\text { health community. CDC WONDER allows accessing statistical } \\
\text { research data and reports published by CDC and querying } \\
\text { numeric data sets on CDC's computers [CDC 2010w]. } \\
\text { Data Source: WONDER Online Databases } \\
\text { Organization: The Centers for Disease Control and Prevention } \\
\text { (CDC) } \\
\text { Format: HTML, chart and map images (bitmaps), ASCII, } \\
\text { spreadsheet } \\
\text { Classification: Resources, Controlling Documents, Demographic } \\
\text { and Behavioral }\end{array}$ \\
\hline CDC.gov Widgets and Gadgets & $\begin{array}{l}\text { Description: CDC.gov provides content in several useful ways, } \\
\text { via our e-mail updates, podcasts and RSS feeds. Our newest } \\
\text { features are the Flu Updates, Emergency Text Messages and the } \\
\text { CDC Data and Statistics Widget. Widgets are online applications } \\
\text { built by one Web site that can be displayed onto another Web } \\
\text { site. A widget is a CDC.gov application that displays the featured } \\
\text { content directly on your web page. You can embed content in } \\
\text { personalized home pages, blogs, and other sites. Once you’ve } \\
\text { added the widget, there’s no technical maintenance. CDC.gov } \\
\text { will update the content automatically. Available widgets include } \\
\text { Adult BMI Calculator, H1N1 (Swine Flu), Fraudulent H1N1 } \\
\text { Products, H1N1 School Guidance, Pet Health and Safety, Public } \\
\text { Health Image Library Image of the Day, Five Minutes or Less for } \\
\text { Health, Smoking and Tobacco Use, Flu IQ, Seasonal Flu } \\
\text { Updates, National Environmental Public Health Tracking } \\
\text { Program, CDC Text Messages, etc. [CDC 2010v]. } \\
\text { Data Source: CDC.gov } \\
\text { Organization: Centers for Disease Control and Prevention } \\
\text { Format: TXT, RSS } \\
\text { Classification: Incidents, Demographic and Behavior, } \\
\text { Environment, Controlling Document }\end{array}$ \\
\hline Clinical Data Repository (CDR) & $\begin{array}{l}\text { Description: The Clinical Center installed a hospital-wide, real- } \\
\text { time computerized medical information system (MIS) in } 1976 . \\
\text { This system supports the Clinical Center's dual responsibilities of } \\
\text { providing quality patient care and collecting research data. The }\end{array}$ \\
\hline
\end{tabular}




\begin{tabular}{|c|c|}
\hline & $\begin{array}{l}\text { Clinical Data Repository (CDR) is a new facility that will house } \\
\text { all electronic data collected at the clinical center from the time } \\
\text { MIS was installed (1975) until today. The CDR will be } \\
\text { continually updated with current data and will be the single place } \\
\text { to find information for clinical, research, and administrative use } \\
\text { [NIH 2010a]. } \\
\text { Data Source: CDR Version 1.4, CCMIS (Mac/MIS, Web/MIS } \\
\text { 3.0) } \\
\text { Organization: National Institute of health (NIH) } \\
\text { Format: Clinical Data Repository (CDR) } \\
\text { Classification: Demographic and Behavior }\end{array}$ \\
\hline $\begin{array}{l}\text { Directory of Information Resources } \\
\text { Online (DIRLINE) }\end{array}$ & $\begin{array}{l}\text { Description: DIRLINE (Directory of Information Resources } \\
\text { Online) is the National Library of Medicine's online database } \\
\text { containing location and descriptive information about a wide } \\
\text { variety of information resources including organizations, research } \\
\text { resources, projects, and databases concerned with health and } \\
\text { biomedicine. DIRLINE contains over 8,500 records and focuses } \\
\text { primarily on health and biomedicine, although it also provides } \\
\text { limited coverage of some other special interests. These } \\
\text { information resources fall into many categories including federal, } \\
\text { state, and local government agencies; information and referral } \\
\text { centers; professional societies; self-help groups and voluntary } \\
\text { associations; academic and research institutions and their } \\
\text { programs; information systems and research facilities. Topics } \\
\text { include HIV/AIDS, maternal and child health, most diseases and } \\
\text { conditions including genetic and other rare diseases, health } \\
\text { services research and technology assessment. Each record may } \\
\text { contain information on the publications, holdings, and services } \\
\text { provided [NIH 2010b]. } \\
\text { Data Source: DIRLINE } \\
\text { Organization: The National Library of Medicine (NLM) } \\
\text { Format: Report } \\
\text { Classification: Resources, Controlling Documents }\end{array}$ \\
\hline Drug Information Portal & $\begin{array}{l}\text { Description: The Drug Information Portal, a free web resource, } \\
\text { provides an informative, user-friendly portal to current drug } \\
\text { information for over 15,000 drugs. Links to sources span the } \\
\text { breadth of the National Library of Medicine (NLM), the National } \\
\text { Institutes of Health (NIH) and other government agencies. } \\
\text { Current information regarding consumer health, clinical trials, } \\
\text { AIDS-related drug information, MeSH pharmacological actions, } \\
\text { PubMed biomedical literature, and physical properties and } \\
\text { structure can be retrieved by searching on a drug name. A varied } \\
\text { selection of focused topics in medicine and drug-related } \\
\text { information is also available from displayed subject headings } \\
\text { [NIH 2010c]. } \\
\text { Data Source: Drug Information Portal } \\
\text { Organization: The National Library of Medicine (NLM) } \\
\text { Format: Report } \\
\text { Classification: Resources, Controlling Document }\end{array}$ \\
\hline
\end{tabular}




\begin{tabular}{|c|c|}
\hline FedStats & $\begin{array}{l}\text { Description: FedStats provides access to the full range of official } \\
\text { statistical information produced by the Federal Government } \\
\text { without having to know in advance which Federal agency } \\
\text { produces which particular statistic. With convenient searching } \\
\text { and linking capabilities to more than } 100 \text { agencies that provide } \\
\text { data and trend information on such topics as economic and } \\
\text { population trends, crime, education, health care, aviation safety, } \\
\text { energy use, and farm production [FEDSTATS 2010]. } \\
\text { Data Source: www.fedstats.gov } \\
\text { Organization: The Federal Interagency Council on Statistical } \\
\text { Policy } \\
\text { Format: HTML, spreadsheets } \\
\text { Classification: Resources, Demographic and Behavior, } \\
\text { Environment, Controlling Documents }\end{array}$ \\
\hline Haz-Map & $\begin{array}{l}\text { Description: Haz-Map is an occupational health database } \\
\text { designed for health and safety professionals and for consumers } \\
\text { seeking information about the health effects of exposure to } \\
\text { chemicals and biological agents at work. Haz-Map links jobs and } \\
\text { hazardous tasks with occupational diseases and their symptoms. } \\
\text { It is one of the products and services made available by the } \\
\text { National Library of Medicine’s (NLM) Toxicology and } \\
\text { Environmental Health Information Program. Haz-Map includes } \\
\text { three categories: hazardous agents, occupational diseases, and } \\
\text { high risk jobs [NIH 2010d]. } \\
\text { Data Source: Haz-Map } \\
\text { Organization: The National Library of Medicine (NLM) } \\
\text { Format: Report } \\
\text { Classification: Demographic and Behavior, Environment, } \\
\text { Controlling Documents }\end{array}$ \\
\hline $\begin{array}{l}\text { Healthcare Cost and Utilization } \\
\text { Project (HCUP) Databases }\end{array}$ & $\begin{array}{l}\text { Description: Healthcare Cost and Utilization Project (HCUP) } \\
\text { databases bring together the data collection efforts of State data } \\
\text { organizations, hospital associations, private data organizations, } \\
\text { and the Federal government to create a national information } \\
\text { resource of patient-level health care data (HCUP Partners). } \\
\text { HCUP includes the largest collection of longitudinal hospital care } \\
\text { data in the United States, with all-payer, encounter-level } \\
\text { information beginning in 1988. These databases enable research } \\
\text { on a broad range of health policy issues, including cost and } \\
\text { quality of health services, medical practice patterns, access to } \\
\text { health care programs, and outcomes of treatments at the national, } \\
\text { State, and local market levels [AHRQ 2010b]. } \\
\text { Data Source: Nationwide Inpatient Sample (NIS), Kids' } \\
\text { Inpatient Database (KID), Nationwide Emergency Department } \\
\text { Sample (NEDS), State Inpatient Databases (SID), State } \\
\text { Ambulatory Surgery Databases (SASD), and State Emergency } \\
\text { Department Databases (SEDD) } \\
\text { Organization: The Agency for Healthcare Research and Quality } \\
\text { (AHRQ) }\end{array}$ \\
\hline
\end{tabular}




\begin{tabular}{|c|c|}
\hline & $\begin{array}{l}\text { Format: PDF, HTML } \\
\text { Classification: Demographic and Behavior, Resources, } \\
\text { Controlling Documents }\end{array}$ \\
\hline Healthy People 2010 Database & $\begin{array}{l}\text { Description: DATA2010 is an information system developed by } \\
\text { staff of the division of Health Promotion Statistics of the National } \\
\text { Center for Health Statistics, CDC, and contains the most recent } \\
\text { monitoring data for tracking Healthy People } 2010 \text {. With this } \\
\text { system, world-wide users have the ability to view the data } \\
\text { collected to track Healthy People } 2010 \text { objectives, with national } \\
\text { baseline and monitoring data for each Healthy People } 2010 \\
\text { objective. Users can select data options to create and browse real- } \\
\text { time tables and graphs of the baseline and tracking year data for } \\
\text { all } 28 \text { health focus areas, as well as the leading health indicators. } \\
\text { This interactive system allows users to query an updated database } \\
\text { and construct tables. Tables can be constructed for specific } \\
\text { objectives, or objectives identified by focus areas, data source, or } \\
\text { by select population [CDC 2010x]. } \\
\text { Data Source: DATA2010 } \\
\text { Organization: National Center for Health Statistics (NCHS) of } \\
\text { the Centers for Disease Control and Prevention (CDC) } \\
\text { Format: Table and Graph } \\
\text { Classification: Controlling Documents, Demographic and } \\
\text { Behavior }\end{array}$ \\
\hline Hospital Compare & $\begin{array}{l}\text { Description: Hospital Compare is used to find information on } \\
\text { how well hospitals care for patients with certain medical } \\
\text { conditions or surgical procedures, and results from a survey of } \\
\text { patients about the quality of care they receives during a recent } \\
\text { hospital stay. The data provided includes process of care, } \\
\text { mortality, and readmission quality measures. The collection } \\
\text { period for the measures is generally } 12 \text { months. However, some } \\
\text { measures may be based upon fewer than } 12 \text { months. Generally, } \\
\text { the Hospital Compare quality measures are refreshed the third } \\
\text { month of each quarter [CMS 2010]. } \\
\text { Data Source: Medicare Hospital Compare } \\
\text { Organization: Centers for Medicare and Medicaid Services } \\
\text { (CMS) of Department of Health and Human Services, Hospital } \\
\text { Quality Alliance } \\
\text { Format: CSV, dbf } \\
\text { Classification: Resources, Controlling Documents }\end{array}$ \\
\hline $\begin{array}{l}\text { Hospital Electronic Health Records } \\
\text { (HER) Adoption Database }\end{array}$ & $\begin{array}{l}\text { Description: The Hospital HER Adoption Database } 2010 \text { is } \\
\text { based on a survey of U.S. hospitals tracking the adoption of } \\
\text { electronic health records (HER), also known as electronic } \\
\text { medical records (EMR). The data included are hospital specific. } \\
\text { The database is used to determine where hospitals are along the } \\
\text { technology adoption curve regarding electronic clinical } \\
\text { documentation, results viewing, computerized provider order } \\
\text { entry, decision support, and bar coding; find out where these } \\
\text { functions are implemented in the hospital: emergency }\end{array}$ \\
\hline
\end{tabular}




\begin{tabular}{|c|c|}
\hline & $\begin{array}{l}\text { department, ICU, general medical/surgical, specialty, onsite } \\
\text { ambulatory practices, and offsite ambulatory practices; and } \\
\text { understand the capabilities of hospital's electronic systems } \\
\text { [AHADATA 2010b]. } \\
\text { Data Source: Database } \\
\text { Organization: American Hospital Association (AHA) } \\
\text { Format: PDF, Microsoft Excel file } \\
\text { Classification: Demographic and Behavior, Resources, } \\
\text { Controlling Documents }\end{array}$ \\
\hline $\begin{array}{l}\text { National Emergency Medical } \\
\text { Services (EMS) Information System } \\
\text { (NEMSIS) }\end{array}$ & $\begin{array}{l}\text { Description: The Hazardous Substances Emergency Events } \\
\text { Surveillance (HSEES) system was established to collect and } \\
\text { analyze information about acute releases of hazardous substances } \\
\text { and threatened releases that result in a public health action such } \\
\text { as an evacuation. The goal of HSEES is to reduce the morbidity } \\
\text { (injury) and mortality (death) that result from hazardous } \\
\text { substances events, which are experienced by first responders, } \\
\text { employees, and the general public. The HSEES system data and } \\
\text { prevention outreach are critical for identifying, preventing, and } \\
\text { mitigating the consequences of terrorist threats against our } \\
\text { chemical infrastructure. Fourteen state health departments } \\
\text { currently have cooperative agreements with ATSDR to } \\
\text { participate in HSEES: Colorado, Florida, Iowa, Louisiana, } \\
\text { Michigan, Minnesota, New Jersey, New York, North Carolina, } \\
\text { Oregon, Texas, Utah, Washington, and Wisconsin [NEMSIS } \\
\text { 2010]. } \\
\text { Data Source: NEMSIS NHTSA Dataset Version } 3 \\
\text { Organization: National Highway Traffic Safety Administration } \\
\text { (NHTSA); Health Resources and Services Administration } \\
\text { (HRSA); CDC; University of Utah; University of North Carolina } \\
\text { Format Used: XSD } \\
\text { Classification: Demographic and Behavioral }\end{array}$ \\
\hline $\begin{array}{l}\text { National Incident Management } \\
\text { System - Incident Resource } \\
\text { Inventory System (NIMS-IRIS) }\end{array}$ & $\begin{array}{l}\text { Description: National Incident Management System - Incident } \\
\text { Resource Inventory System (NIMS-IRIS) is a database } \\
\text { management tool that allows emergency responders to enter } \\
\text { typed resources and select specific resources for mutual aid } \\
\text { purposes based upon mission requirements, capability of } \\
\text { resources, and response time. NIMS-IRIS tracks equipment, } \\
\text { communications, contracts, facilities, responders, services, } \\
\text { supplies, and teams [FEMA 2010]. } \\
\text { Data Source: NIMS-IRIS Version } 2.2 \\
\text { Organization: Federal Emergency Management Agency } \\
\text { (FEMA) } \\
\text { Format: EDXL } \\
\text { Classification: Resources }\end{array}$ \\
\hline $\begin{array}{l}\text { Rand Public Health Preparedness } \\
\text { Database }\end{array}$ & $\begin{array}{l}\text { Description: The Rand Corporation database, funded by the U.S. } \\
\text { Department of Health and Human Services, provides access to } \\
\text { numerous public health preparedness exercises. It is primarily } \\
\text { intended for state and local public health officials. The database }\end{array}$ \\
\hline
\end{tabular}




\begin{tabular}{|c|c|}
\hline & $\begin{array}{l}\text { provides a list of possible exercises performed along with criteria } \\
\text { rating the success of each exercise. There are fourteen design } \\
\text { criteria used to rate each exercise. These criteria are: 1) clearly } \\
\text { stated goals; 2) clearly stated objectives; 3) the objectives are } \\
\text { appropriate given the goals; 4) each objective is addressed during } \\
\text { the exercise; 5) objectives are measurable; 6) the scenario is } \\
\text { appropriate given the goals and objectives; 7) the scenario is } \\
\text { internally consistent; 8) scenario is “a realistic depiction of the } \\
\text { capabilities and resources likely to be available to a participating } \\
\text { health jurisdiction;” 9) clear guidance about participants; 10) all } \\
\text { participants are engaged; 11) exercise can be replicated; 12) } \\
\text { results in action items; 13) feedback is solicited from participants; } \\
\text { 14) can be completed within the given timeframe. The goal of } \\
\text { this database is “to identify the best exercises to help local and } \\
\text { state public health departments prepare for public health } \\
\text { emergencies.” [RAND 2010] } \\
\text { Data Source: Rand Public Health Preparedness Exercise } \\
\text { Database } \\
\text { Organization: RAND Corporation, Department of Health and } \\
\text { Human Services (HHS) } \\
\text { Format: } \\
\text { Classification: Training, Resources }\end{array}$ \\
\hline $\begin{array}{l}\text { Risk Group Database for Risk } \\
\text { Group Classification for Infectious } \\
\text { Agents }\end{array}$ & $\begin{array}{l}\text { Description: In many countries, including the United States, } \\
\text { infectious agents are categorized in risk groups based on their } \\
\text { relative risk. Depending on the country and/or organization, this } \\
\text { classification system might take the following factors into } \\
\text { consideration: pathogenicity of the organism, mode of } \\
\text { transmission and host range, availability of effective preventive } \\
\text { measures (e.g., vaccines), availability of effective treatment (e.g., } \\
\text { antibiotics), and other factors. The Risk group classifications } \\
\text { used in the Risk Group Database are primarily used in the } \\
\text { research environment as part of a comprehensive bio-safety risk } \\
\text { assessment. The Risk Group database provides four search } \\
\text { engines: search bacteria, search virus, search fungi, and search } \\
\text { parasites [ABSA 2010]. } \\
\text { Data Source: ABSA Risk Group Database } \\
\text { Organization: American Biological Safety Association (ABSA) } \\
\text { Format: } \\
\text { Classification: Controlling Documents, Demographic and } \\
\text { Behavior }\end{array}$ \\
\hline $\begin{array}{l}\text { The Emergency Response Safety } \\
\text { and Health Database }\end{array}$ & $\begin{array}{l}\text { Description: The Emergency Response Safety and Health } \\
\text { Database is a rapidly accessible occupational safety and health } \\
\text { database developed by NIOSH for the emergency response } \\
\text { community. The ERSH-DB contains accurate and concise } \\
\text { information on high-priority chemical, biological and radiological } \\
\text { agents that could be encountered by personnel responding to a } \\
\text { terrorist event. The information contained in the ERSH-DB } \\
\text { represents a compilation of material from a diverse array of } \\
\text { sources, and is intended to address the safety and health }\end{array}$ \\
\hline
\end{tabular}




\begin{tabular}{|c|c|}
\hline & $\begin{array}{l}\text { information needs of a wide range of emergency response } \\
\text { personnel, including, but not limited to, the fields of fire and } \\
\text { rescue, emergency medicine, law enforcement, emergency } \\
\text { management, public health, safety and health, and mortuary and } \\
\text { funeral. As a central source of information, the ERSH-DB allows } \\
\text { diverse segments of the emergency response community to share } \\
\text { a wealth of information that is not readily accessible and to avoid } \\
\text { duplication of effort [CDC 2010a]. } \\
\text { Data Source: ERSH-DB } \\
\text { Organization: The Centers for Disease Control and Prevention } \\
\text { (CDC); The National Institute of Occupational Safety \& Health } \\
\text { (NIOSH) } \\
\text { Format Used: text, table } \\
\text { Classification: Controlling Documents }\end{array}$ \\
\hline TheDataWeb Browser & $\begin{array}{l}\text { Description: TheDataWeb is a network of online data libraries } \\
\text { that the DataFerrett accesses the data through. DataFerrett is a } \\
\text { unique data analysis and extraction tool—-with recoding } \\
\text { capabilities-to customize federal, state, and local data to suit the } \\
\text { user's requirements. (FERRETT stands for Federated Electronic } \\
\text { Research, Review, Extraction, and Tabulation Tool.) Data topics } \\
\text { of TheDataWeb include census data, economic data, health data, } \\
\text { income and unemployment data, population data, labor data, } \\
\text { cancer data, crime and transportation data, family dynamics, vital } \\
\text { statistics data, etc. [THEDATAWEB 2010] } \\
\text { Data Source: BetaDataFerrett } \\
\text { Organization: U.S. Census Bureau } \\
\text { Format: XML/CAP 1.1, ATOM, RSS } \\
\text { Classification: Controlling Documents, Demographic and } \\
\text { Behavior, Resources }\end{array}$ \\
\hline $\begin{array}{l}\text { TOXicology Data NETwork } \\
\text { (TOXNET) }\end{array}$ & $\begin{array}{l}\text { Description: TOXNET (TOXicology Data NETwork) is a cluster } \\
\text { of databases covering toxicology, hazardous chemicals, } \\
\text { environmental health and related areas. It is managed by the } \\
\text { Toxicology and Environmental Health Information Program } \\
\text { (TEHIP) in the Division of Specialized Information Services } \\
\text { (SIS) of the National Library of Medicine (NLM). Toxicology } \\
\text { databases include Hazardous Substances Data Bank (HSDB), } \\
\text { Integrated Risk Information System (IRIS), International Toxicity } \\
\text { Estimates for Risk (ITER), Chemical Carcinogenesis Research } \\
\text { Information System (CCRIS), Genetic Toxicology (GENE- } \\
\text { TOX), Toxicology interactive guide (Tox Town), Household } \\
\text { Products Database, Occupational Toxicology Database (Haz- } \\
\text { Map), toxic chemicals released on map (TOXMAP), Drugs and } \\
\text { Lactation (LacMed), and Carcinogenic Potency Database } \\
\text { (CPDB) [NIH 2010e]. } \\
\text { Data Source: TOXNET } \\
\text { Organization: The National Library of Medicine (NLM) } \\
\text { Format: Report, XML } \\
\text { Classification: Controlling Documents, Demographic and } \\
\text { Behavior, Environment }\end{array}$ \\
\hline
\end{tabular}




\begin{tabular}{|l|l|}
\hline $\begin{array}{l}\text { Weapons of Mass Destruction } \\
\text { (WMD), Emergency Management } \\
\text { and Medical Websites }\end{array}$ & $\begin{array}{l}\text { Description: A comprehensive list of internet sites of use for } \\
\text { emergency planning and in particular Weapons of Mass } \\
\text { Destruction (WMD) and medical emergency planning [YNHHS } \\
\text { 2010]. } \\
\text { Data Source: Yale New Haven Center for Emergency } \\
\text { Preparedness and Disaster Response Yale New Haven Health } \\
\text { System } \\
\text { Organization: Yale New Haven Health System } \\
\text { Format Used: N/A } \\
\text { Classification: Controlling Documents }\end{array}$ \\
\hline $\begin{array}{l}\text { Web-based Injury Statistics Query } \\
\text { and Reporting System (WISQARS) }\end{array}$ & $\begin{array}{l}\text { Description: The Web-based Injury Statistics Query and } \\
\text { Reporting System (WISQARS) is an interactive database system } \\
\text { that provides customized reports of injury-related data. The } \\
\text { database includes fatal injury data (from the National Vital } \\
\text { Statistics System), nonfatal injury data (from the National } \\
\text { Electronic Injury Surveillance System), and violent deaths (from } \\
\text { the National Violent Death Reporting System (NVDRS) [CDC } \\
\text { 2010z]. } \\
\text { Data Source: WISQARS } \\
\text { Organization: Centers for Disease Control and Prevention } \\
\text { (CDC) } \\
\text { Format: CSV } \\
\text { Classification: Incidents }\end{array}$ \\
\hline
\end{tabular}

\section{Discussions and Recommendations}

This section is intended to capture practices and issues relevant to program sponsors, project managers, researchers, developers, and implementers of $M \& S$ of healthcare systems for homeland security applications. The resources presented in section 6 and research, development and implementation experiences are used to identify the best practices to be followed for future efforts and to provide uncertainties, cautions and warnings for use of such applications. Further, the resources in section 6 are compared with the information in sections 4 and 5 to identify the unmet needs and requirements. These unmet needs and requirements are used to identify and prioritize the research, development, standards, and implementation issues that should be addressed going forward. This section hence provides a summary of discussion topics and recommendations that are divided into three major areas:

- Identification of best practices (Section 7.1)

- Uncertainties, cautions and warnings regarding expectations of these models and simulations (Section 7.2)

- Research, development, standards and implementation issues that may need to be addressed by the research community, program sponsors, and stakeholders to improve the quality and utility of incident management models and simulations (Section 7.3)

\subsection{Best Practices}


Best practices are really only effective if a methodology is well defined for a given problem solving approach. For example, the LUMAS model shows how learning influences a documented methodology, and the link between L and M in the LUMAS model is where best practice is encountered by the user of a methodology. Computer models and simulations are tools in a variety of problem solving methodologies such as operations research, systems engineering, and management science, where methodology is defined as a collection of related processes, methods, and tools. Methodologies evolve as they are used by practitioners to address new problems and as new technologies and tools are developed to support them. Methodological advances are encouraged by documenting existing methods, processes and tools and by updating these periodically based on lessons learned and best practice from practical experience. This section will identify recommended approaches and best practices for solving different types of hazardous material release modeling problems.

A variety of M\&S approaches, methodologies, and tools are currently available. Some are more suitable to solving certain classes of problems than others. This section will identify recommended approaches and best practices for solving different types of healthcare modeling problems.

- Provide tools that can be used at the local level for healthcare systems analysis, evaluation, or training purposes

- Use various test and validation methods

- Provide tools that do not require sophisticated and expensive system support

- Provide distributed web-based tools that allow health care organizations to develop and run custom exercises.

\subsection{Uncertainties, Cautions and Warnings}

This sub-section is intended to highlight and document the limitations associated with M\&S applications to minimize improper use and highlight potential areas for further development. M\&S application requires significant effort and hence they should be utilized only when appropriate, i.e., they should be considered for complex problems that cannot be addressed using other analytical options. The level of detail and specificity achieved by using the most sophisticated models and simulations may not be practical or necessary for all assets, systems, or networks. In these circumstances, a simplified dependency and interdependency analysis based on expert judgment may provide sufficient insight to make informed risk management decisions in a timely manner [DHS 2009].

For applications that are identified as suitable for M\&S applications, it should be recognized that models provide results with varying levels of error and uncertainty. Analysts should ensure that decision-makers understand the uncertainties in M\&S results and other limitations such as the ones listed below. Models provide results with varying levels of error and uncertainty. This sub-section is intended to highlight and document the limitations associated with M\&S applications to minimize improper use and highlight potential areas for further development.

- Epidemic models are particularly susceptible to variations in predicted results due to difficulties in precisely modeling human behaviors and random occurrences of transmission of diseases.

- $\quad$ Training exercises may not create the stress conditions and state of mind in the healthcare systems personnel that would occur during a real incident or epidemic.

- Data inconsistencies between simulated exercises and real incidents may affect the results and perceptions.

- Communication difficulties and incompatibilities between systems may not be accurately reflected in training exercises. 


\subsection{Research, Development, Standards, and Implementation Issues}

A number of research, development, standards, and implementation issues remain to be addressed. An initial straw man list follows:

- Identification of appropriate models, simulations, tools, and databases to address healthcare system analysis and training needs

- Increasing reality in healthcare $M \& S$ training exercises and devices

- Identification of common models, simulations, tools, and databases that can be shared by the user community

- Identification of technical gaps and needs for models, simulations, tools, and databases

- Development of system requirements specifications for healthcare models, simulations, tools, and databases

- Development of systems dynamics models for addressing strategic issues for different healthcare systems and incident scenarios

- Development of mechanisms to enable access to and usage of healthcare M\&S applications by the healthcare providers, partners, and emergency response personnel

- Development of simulation application architectures to enable module integration and standard data interfaces to import data from external databases

- Use of a system-of-systems engineering approach to the development of applications

- Use of UML/SysML in specification of healthcare systems and M\&S applications

- Development of M\&S applications as open systems

- Use of object-oriented models in healthcare M\&S

- Integration of healthcare models and simulations

- Establishment of security and protection mechanisms for sensitive data

- Ownership and usage of publicly vs. privately developed models, simulations, tools, and databases

- Return on investment to stakeholders and sponsors for research projects

\section{Conclusion}

This initial version of the document is the starting point of an effort to capture the current knowledge relevant to M\&S of healthcare for homeland security applications. It identifies the needs, translates them into requirements and provides summary information on resources available to meet the needs and requirements. The information on needs, requirements, and resources is used together with research, development, and implementation experiences to distill practices and issues for future efforts.

This version will be used to facilitate input from domain experts in a workshop setting. It is hoped that the next version updated with such input will provide value as a reference for program managers, project managers, researchers, developers, and implementers of M\&S for healthcare for homeland security applications. Use of the updated document as a common reference may help increase the awareness across the associated communities and help enhance collaborative efforts for homeland security applications of M\&S for healthcare.

\section{References}

[AAI 2007]

Healthcare Modeling Studio. Automation Associates Inc. Available via: http://www.blueminegroup.com/aai/pos_healthcare_modeling_studio.asp 
[ABSA 2010]

[ADL 2011]

[AHADATA 2010a]

[AHADATA 2010b]

[AHRQ 2010a]

[AHRQ 2010b]

[ANL 2011]

[ANSI 2010]

[ANSI 2011a]

[ANSI 2011b]

[ANSI 2011c]

[ASTM 2011]

[AUTODESK 2010]

[Balci 1998] [accessed Jan. 3, 2011]

Risk Group Classification for Infectious Agents. American Biological Safety Association (ABSA). Available via: http://www.absa.org/riskgroups/bacteria.html [Accessed Dec. 12, 2010] Advanced Distributed Learning Sharable Content Object Reference Model (SCORM). Available via:

http://www.adlnet.gov/Technologies/scorm/default.aspx [accessed Jan. 10, 2011].

Health Care Statistics and Market Research: AHA Data. American Hospital Association (AHA). Available via:

http://www.ahadata.com/ahadata_app/index.jsp [Accessed Dec. 12, 2010]

Hospital Electronic Health Records (HER) Adoption Database. American Hospital Association (AHA). Available via:

http://www.ahadata.com/ahadata/html/EHRdatabase.html [Accessed Dec. 12, 2010]

Community-Based Mass Prophylaxis. Agency for Healthcare Research and Quality (AHRQ). Available via:

http://www.ahrq.gov/research/cbmprophyl/cbmpro.htm [Accessed Dec. 12, 2010]

Healthcare Cost and Utilization Project (HCUP). Agency for Healthcare Research and Quality (AHRQ). Available via:

http://www.ahrq.gov/data/hcup/ [Accessed Dec. 12, 2010]

CVMDM: Community Vaccination and Mass Dispensing Model.

Decision and Information Sciences, Argonne National Laboratory.

Available via: http://www.dis.anl.gov/projects/cvmdm.html [accessed Jan. 3, 2011]

http://webstore.ansi.org/RecordDetail.aspx?sku=ANSI+INCITS+398-2008 [Accessed Dec. 12, 2010]

American National Standards Institute (ANSI) Standards Store - Spatial Data Standard for Facilities, Infrastructure, and Environment (SDSFIE). Available via:

http://webstore.ansi.org/RecordDetail.aspx?sku=ANSI+INCITS+3532006 [accessed Jan. 15, 2011].

American National Standards Institute (ANSI) Standards Store Homeland Security Mapping Standard: Point Symbology for Emergency Management. Available via:

http://webstore.ansi.org/RecordDetail.aspx?sku=ANSI+INCITS+4152006 [accessed Mar. 25, 2011].

American National Standards Institute (ANSI) Standards Store - Unified Modeling Language (UML). Available via:

http://webstore.ansi.org/RecordDetail.aspx?sku=ISO\%2fIEC+19501\%3a2

005\&source=google\&adgroup=iso9\&keyword=iso\%2Fiec\%2019501

[accessed Jan. 28, 2011].

ASTM Standards and Engineering Digital Library. ASTM International.

Available via: http://www.astm.org/Standard/index.shtml?complete

[Accessed May 2, 2011]

DXF Format. AutoDesk. Available via:

http://www.autodesk.com/techpubs/autocad/acad2000/dxf/dxf_format.htm [Accessed Dec. 12, 2010]

Verification, Validation, and Testing. In Handbook of Simulation:

Principles, Methodology, Advances, Applications, and Practice. Edited by 
[BMET 2010]

[Breakaway 2010]

[CDC 2010a]

[CDC 2010aa]

[CDC 2010b]

[CDC 2010c]

[CDC 2010d]

[CDC 2010e]

[CDC 2010f]

[CDC 2010g]

[CDC 2010h]

[CDC 2010i]

[CDC 2010j]
J. Banks. Wiley-Interscience.

Interim Life Safety Measures. Wikia. Available via: http://bmet.wikia.com/wiki/Interim_Life_Safety_Measures [Accessed Dec. 12, 2010]

Serious Games for Homeland Security. Breakaway Ltd. Available via: http://www.breakawaygames.com/serious-games/solutions/homeland/ [accessed Jan. 3, 2011]

After a Terrorist Bombing: Health and Safety Information for the General Public. Centers for Disease Control and Prevention (CDC). Available via: http://www.bt.cdc.gov/masscasualties/afterbombing.asp [accessed Nov. 2, 2010]

The Emergency Response Safety and Health Database. Centers for Disease Control and Prevention (CDC). Available via:

http://www.cdc.gov/NIOSH/ershdb/about.html [Accessed Dec. 12, 2010]

Bioterrorism Readiness Plan: A template for Healthcare Facilities. Centers for Disease Control and Prevention (CDC). Available via:

http://www.cdc.gov/ncidod/dhqp/pdf/bt/13apr99apic-cdcbioterrorism.pdf [Accessed Dec. 12, 2010]

Anthrax: Short and Extended Messages. Centers for Disease Control and Prevention (CDC). Available via:

http://www.bt.cdc.gov/firsthours/anthrax/messages.asp [accessed Nov. 2, 2010]

Facts about the Laboratory Response Network. Centers for Disease Control and Prevention (CDC). Available via:

http://www.bt.cdc.gov/lrn/factsheet.asp [accessed Nov. 2, 2010]

Guidance for Protecting Building Environments from Airborne Chemical, Biological, or Radiological Attacks. Centers for Disease Control and Prevention (CDC). Available via: http://www.cdc.gov/niosh/docs/2002139/ [accessed Nov. 2, 2010]

Guidance for Public Health Departments and Clinicians Caring for Individuals Who May have Been Recently Exposed to Polonium 210 (Po210). Centers for Disease Control and Prevention (CDC). Available via: http://www.bt.cdc.gov/radiation/isotopes/polonium/clinicians.asp [Accessed Dec. 12, 2010]

Guidelines for Handling Decedents Contaminated with Radioactive Materials. Centers for Disease Control and Prevention (CDC). Available via: http://www.bt.cdc.gov/radiation/pdf/radiation-decedent-guidelines.pdf [Accessed Dec. 12, 2010] Interim Guidelines for Hospital Response to Mass Causalities from a Radiological Incident. Centers for Disease Control and Prevention (CDC). Available via:

http://www.bt.cdc.gov/radiation/pdf/MassCasualtiesGuidelines.pdf [Accessed Dec. 12, 2010]

Interim Recommendations for the Selection and use of Protective Clothing and Respirators against Biological Agents. Centers for Disease Control and Prevention (CDC). Available via:

http://www.bt.cdc.gov/documentsapp/anthrax/protective/10242001protect. asp [accessed Nov. 2, 2010]

Classification of Diseases, Functioning, and Disability. Centers for Disease Control and Prevention (CDC). Available via:

http://www.cdc.gov/nchs/icd.htm [Accessed Dec. 12, 2010] 
[CDC 2010k]

[CDC 2010l]

[CDC 2010m]

[CDC 2010n]

[CDC 2010o]

[CDC 2010p]

[CDC 2010q]

[CDC 2010r]

[CDC 2010s]

[CDC 2010t]

[CDC 2010u]

[CDC 2010v]

[CDC 2010w]

[CDC 2010x]

[CDC 2010y]
Managing Hazardous Materials Incidents (MHMIs). Centers for Disease Control and Prevention (CDC). Available via: http://www.atsdr.cdc.gov/MHMI/index.asp [Accessed Dec. 12, 2010] Mass Casualty Event Preparedness and Response. Centers for Disease Control and Prevention (CDC). Available via: http://www.bt.cdc.gov/masscasualties/ [Accessed Dec. 12, 2010] NIOSH Pocket Guide to Chemical Hazards. Centers for Disease Control and Prevention (CDC). Available via: http://www.cdc.gov/niosh/npg/ [Accessed Dec. 12, 2010]

Agency for Toxic Substances and Disease Registry - Redirect. Centers for Disease Control and Prevention (CDC). Available via:

http://www.atsdr.cdc.gov/MHMI/mmg170.html [Accessed Dec. 12, 2010]

Population Monitoring in Radiation Emergencies. Centers for Disease

Control and Prevention (CDC). Available via:

http://www.bt.cdc.gov/radiation/pdf/population-monitoring-guide.pdf [accessed Nov. 2, 2010]

Preparing for a Terrorist Bombing: A Common Sense Approach. Centers for Disease Control and Prevention (CDC). Available via: http://www.bt.cdc.gov/masscasualties/preparingterroristbombing.asp [Accessed Dec. 12, 2010]

The Public Health Response to Biological and Chemical Terrorism. Centers for Disease Control and Prevention (CDC). Available via: http://www.bt.cdc.gov/documents/planning/planningguidance.pdf [accessed Nov. 2, 2010]

Recognition of Illness Associated with the Intentional Release of a Biologic Agent. Centers for Disease Control and Prevention (CDC). Available via:

http://www.cdc.gov/mmwr/preview/mmwrhtml/mm5041a2.htm [accessed Nov. 2, 2010]

Roundtable on Population Monitoring Following a Nuclear/Radiological Incident. Centers for Disease Control and Prevention (CDC). Available via: http://www.bt.cdc.gov/radiation/pdf/population-monitoringroundtable.pdf [accessed Nov. 2, 2010]

Shelter-in-Place in a Radiation. Centers for Disease Control and Prevention (CDC). Available via:

http://www.bt.cdc.gov/radiation/shelter.asp [Accessed Dec. 12, 2010]

Behavioral Risk Factor Surveillance System (BRFSS). Centers for

Disease Control and Prevention (CDC). Available via:

http://www.cdc.gov/brfss/about.htm [Accessed Dec. 12, 2010]

CDC.gov Widgets and Gadgets. Centers for Disease Control and

Prevention (CDC). Available via: http://www.cdc.gov/widgets/ [Accessed Dec. 12, 2010]

CDC WONDER Online Databases. Centers for Disease Control and Prevention (CDC). Available via: http://wonder.cdc.gov/ [Accessed Dec. $12,2010]$

Data2010: the Healthy People 2010 Database. Centers for Disease Control and Prevention (CDC). Available via: http://wonder.cdc.gov/data2010/

[Accessed Dec. 12, 2010]

Ambulatory Health Care Data. Centers for Disease Control and Prevention (CDC). Available via: http://www.cdc.gov/nchs/ahcd.htm 
[CDC 2010z]

[CENSUS 2010]

[Checkland 2000]

[CIMIT 2002]

[CIMIT 2010]

[CMS 2010]

[Connelly 2004]

[CreateASoft 2011]

[DEVS 2011]

[DHS 2003]

[DHS 2008a]

[DHS 2008b]

[DHS 2009]

[DHS 2010a]

[DHS 2010b]
[Accessed Dec. 12, 2010]

Injury Prevention and Control: Data and Statistics. Centers for Disease Control and Prevention (CDC). Available via:

http://www.cdc.gov/injury/wisqars/index.html [Accessed Dec. 12, 2010] American Housing Survey (AHS). U.S. Census Bureau. Available via: http://www.census.gov/hhes/www/housing/ahs/ahs.html [Accessed Dec. 12, 2010]

Checkland, Peter. SSM: A Thirty-Year Retrospective. Systems Research and Behavioral Science, November 2000.

RIPS: Real-time Incident Preparedness Simulator. Center for Integration of Medicine and Innovative Technology. Available via:

http://www.medicalsim.org/rips.htm [accessed Jan. 3, 2011]

CIMIT: Center for Integration of Medicine and Innovative Technology.

Available via: http://www.cimit.org/ [accessed Dec. 29, 2010]

Hospital Compare. Center for Medicare and Medicaid Services.

Available via:

http://www.cms.gov/HospitalQualityInits/11_HospitalCompare.asp

[Accessed Dec. 12, 2010]

Connelly, L.G., and A.E. Bair, 2004. Discrete Event Simulation of

Emergency Department Activity: A Platform for System-level Operations

Research. Academic Emergency Medicine, 11(11):1177-1185. Available via: http://heather.cs.ucdavis.edu/ matloff/156/PLN/Bair.pdf [accessed Jan. 3, 2011].

SimCare Process Simulator. CreateASoft. Available via: http://www.createasoft.com/processImprovementSimulator/leanProcessSi mulationSoftware/SimCareProcessSimulator7.2.html [accessed Jan. 3, 2011].

Discrete-Event Modeling and Simulation (DEVS) Standardization Group. Available via: http://cell-devs.sce.carleton.ca/devsgroup/ [accessed Jan. 25, 2011].

HSPD-5 Homeland Security Presidential Directive \#5 http://www.dhs.gov/xnews/releases/press_release_0105.shtm [accessed November 15, 2010]

National Incident Management System. U.S. Department of Homeland Security. Available via:

http://www.fema.gov/pdf/emergency/nims/NIMS_core.pdf [accessed April 3, 2011]

National Response Framework. U.S. Department of Homeland Security. Available via: http://www.fema.gov/pdf/emergency/nrf/nrf-core.pdf [accessed April 3, 2011] National Infrastructure Protection Plan. U.S. Department of Homeland Security. Available via: http://www.dhs.gov/xlibrary/assets/NIPP_Plan.pdf [accessed Feb. 27, 2011]

DHS Lexicon: Terms and Definitions. Office of the Secretary, Executive Secretariat, U.S. Department of Homeland Security. January 2010 edition (with 9/14/2010 update).

Guidance on Initial Responses to a Suspicious Letter/Container with a Potential Biological Threat. Available via: http://cryptome.quintessenz.at/mirror/fbi-dhs-guide.htm [Accessed Dec. 12, 2010] 
[DHS 2011]

[DoD 2006]

[DoD 2009]

[DoD 2010]

[DODCCRP 2011]

[DOL 2010]

[EVMS 2009]

[FEDSTATS 2010]

[FEMA 2010]

[Ferrin 2007]

[FGDC 2010]

[FGDC 2011a]
Healthcare and Public Health Sector Snapshot. U.S. Department of Homeland Security. Available via:

http://www.dhs.gov/files/programs/gc_1188490299862.shtm [accessed April 17, 2011]

VV\&A Recommended Practices Guide (RPG). U.S. Department of Defense Modeling and Simulation Coordination Office. RPG Build 3.0.

September 2006. Available on-line via: http://vva.msco.mil/ [last accessed Oct. 1, 2010].

DoD Modeling and Simulation (M\&S) Verification, Validation, and Accreditation (VV\&A). Department of Defense Instruction Number 5000.61. December 9, 2009. Available on-line via: http://www.dtic.mil/whs/directives/corres/pdf/500061p.pdf [last accessed October 4, 2010]

DoD Modeling and Simulation Glossary. U.S. Department of Defense. March 2010. Available via:

http://www.msco.mil/files/Draft_MS_Glossary_March_B_version.pdf [accessed April 20, 2011]

Katherine Morse. 2004. Web Enabling HLA Compliant Simulations to Support Network Centric Applications. Available via: http://www.dodccrp.org/events/2004_CCRTS/CD/presentations/172.pdf [accessed Mar. 25, 2011]

The Health Insurance Portability and Accountability Act (HIPAA): Portability of Health Coverage. U.S. Department of Labor. Available via: http://www.dol.gov/dol/topic/health-plans/portability.htm [Accessed Dec. 12, 2010]

National Center for Collaboration in Medical Modeling and Simulation. Eastern Virginia Medical School. Available via:

http://www.evms.edu/nccmms/ [accessed Dec. 29, 2010]

FedStats. Fedstats.gov. Available via: http://www.fedstats.gov/ [Accessed Dec. 12, 2010]

National Incident Management System Incident Resource Inventory System (NIMS-IRIS). Federal Emergency Management Agency (FEMA). Available via:

http://www.fema.gov/pdf/emergency/nims/nims_iris_fact_sheet.pdf [Accessed Dec. 12, 2010]

Ferrin, D.M., M.J. Miller, and D.L. McBroom, 2007. Maximizing Hospital Financial Impact and Emergency Department Throughput with Simulation. In Proceedings of the 2007 Winter Simulation Conference, eds. S. G. Henderson, B. Biller, M.-H. Hsieh, J. Shortle, J. D. Tew, and R. R. Barton, 1566-1573. Piscataway, NJ: Institute of Electrical and Electronics

Engineers, Inc. Available via:

http://www.northernlightsnav.com/documents/WSC07\%20ED\%20Sim\%2 0St\%20\%20Mary\%27s\%20v4.pdf [accessed Jan. 3, 2011].

Geographic Information Framework Data Standard. Federal Geographic Data Committee (FGDC). Available via:

http://www.fgdc.gov/standards/projects/FGDC-standardsprojects/framework-data-

standard/GI_FrameworkDataStandard_Part5_GovernmentalUnitBoundari es.pdf [accessed January 31, 2011].

Content Standard for Digital Geospatial Metadata. Federal Geographic Data Committee (FGDC). Available via: 
[FGDC 2011b]

[FGDC 2011c]

[FGDC 2011d]

[FGDC 2011e]

[GEOAPI 2011]

[GEOTIFF 2011]

[HHS 2007]

[HHS 2010a]

[HHS 2010b]

[HL7 2010]

[IEEE 2010]

[IEEE 2011c]

[IFAD 2011]
http://www.fgdc.gov/standards/projects/FGDC-standards-

projects/metadata/base-metadata/?searchterm=FGDC-STD-001 [accessed Mar. 25, 2011].

Content Standard for Digital Geospatial Metadata: Extensions for Remote Sensing Metadata. Federal Geographic Data Committee (FGDC).

Available via:

http://www.fgdc.gov/standards/projects/FGDC-standards-

projects/csdgm_rs_ex/MetadataRemoteSensingExtens.pdf/view?searchter m=FGDC-STD-012 [accessed Mar. 25, 2011].

Geographic Information Framework data Standard. Federal Geographic

Data Committee (FGDC). Available via:

http://www.fgdc.gov/standards/projects/FGDC-standards-

projects/framework-data-standard/framework-data-standard [accessed

Mar. 25, 2011].

Spatial Data Transfer Standard (SDTS). Federal Geographic Data

Committee (FGDC). Available via:

http://www.fgdc.gov/standards/projects/FGDC-standards-

projects/SDTS/?searchterm=sdts [accessed Mar. 25, 2011].

United States National Grid. Federal Geographic Data Committee

(FGDC). Available via:

http://www.fgdc.gov/standards/projects/FGDC-standards-

projects/usng/fgdc_std_011_2001_usng.pdf [accessed Mar. 25, 2011].

GeoAPI 3.0 Standard. GeoAPI Standard Working Group. Available via:

http://www.geoapi.org/charter.html [accessed Mar. 25, 2011].

GeoTIFF FAQ. Available via:

http://www.remotesensing.org/geotiff/faq.html [accessed Mar. 25, 2011].

Public Health \& Healthcare: Critical Infrastructure and Key Resources

Sector-Specific Plan as input to the National Infrastructure Protection Plan

(Redacted). May 2007. Department of Health and Human Services.

Available via:

http://www.phe.gov/Preparedness/planning/cip/Documents/healthssp 08 508.pdf [accessed April 17, 2011]

The Health Insurance Portability and Accountability Act (HIPAA). U.S. Department of Health and Human Services. Available via:

http://www.cms.gov/HIPAAGenInfo/ [Accessed Dec. 12, 2010]

Health Information Privacy. U.S. Department of Human Services.

Available via:

http://www.hhs.gov/ocr/privacy/hipaa/administrative/securityrule/

[Accessed Dec. 12, 2010]

HL7 Standards. Health Level Seven International. Available via:

http://www.hl7.org/implement/standards/index.cfm?ref=nav [Accessed

Dec. 12, 2010]

IEEE 1512-2006 Standard for Common Incident management Message

Sets for Use by Emergency Management Centers. IEEEXplore. Available via: http://ieeexplore.ieee.org/xpl/freeabs_all.jsp?arnumber=1673309

[Accessed Dec. 12, 2010]

IEEE Standard for Modeling and Simulation (M\&S) High Level

Architecture (HLA). IEEEXplore. Available via:

http://ieeexplore.ieee.org/xpl/freeabs_all.jsp?arnumber=803526 [accessed

Mar. 28, 2011].

MUSTER 2.0. IFAD Denmark. Available via: 
[IHS2011a]

[INCOSE 2008]

[ISO 2011b]

[IST 2009]

[Jain 2011]

[JCAHOSTD 2010]

[JCR 2010]

[LANL 2010]

[LeClaire 2009]

[Loud Squirrel 2011]

[Martin 1996]

[MYMIC 2010a]

[MYMIC 2010b]

[NEMA 2010]
http://www.ifad.dk/index.php?option=com_content\&task=view\&id=15\&It emid=31 [accessed Jan. 3, 2011]

IEEE 1278.2 Standard for Distributed Interactive Simulation Communication Services and Profiles. IHS. Available via: http://electronics.ihs.com/document/abstract/ZEVZCBAAAAAAAAAA [accessed Jan. 28, 2011].

International Council on Systems Engineering. INCOSE-TD-2007-00301: Survey of Model-Based Systems Engineering (MBSE) Methodologies. Seattle, WA 98133. 10 June 2008.

ISO Standards. ISO. Available via:

http://www.iso.org/iso/iso_catalogue.htm [accessed Mar. 25, 2011].

Human Patient Simulators - New Dimensions in Training to Treat Mass

Casualties. Institute for Simulation and Training, University of Central

Florida. Available via: http://www.ist.ucf.edu/emt/hps.htm [accessed Dec. 30, 2010]

Jain, S., and C.R. McLean. 2011. Best Practices for Modeling, Simulation and Analysis (MS\&A) for Homeland Security Applications. National

Institute of Standards and Technology. NIST Interagency/Internal Report (NISTIR) 7655.

2006 Hospital Accreditations Standards for Emergency Management

Planning, Emergency management Drills, Infection Control, Disaster

Privileges. Joint Commission on Accreditation of Healthcare

Organizations (JCAHO). Available via:

http://www.efilmgroup.com/efg/blurbimage/JCAHOStdforEmergency.pdf [Accessed Dec. 12, 2010]

2009 Environment of Care Crosswalk. Joint Commission Resources

(JCR). Available via: http://www.jcrinc.com/News/2008/11/7/2009-

Environment-of-Care-Crosswalk-now-Available-for-Hospitals/ [Accessed

Dec. 12, 2010]

NISAC Tools: EpiSimS: Epidemic Simulation System. Los Alamos

National Laboratory. Available via:

http://www.lanl.gov/programs/nisac/episims.shtml [accessed Jan. 3, 2011] LeClaire, R., Hirsch, G.B., and Bandlow, A., 2009. Learning Environment Simulator: A Tool for Local Decision Makers and First Responders. In Proceedings of the 27th International Conference of the System Dynamics Society, July 26 - 30, 2009, Albuquerque, New Mexico, USA. Available via:

http://www.systemdynamics.org/conferences/2009/proceed/papers/P1391. pdf [accessed Jan. 3, 2011]

ED Simulation. Loud Squirrel, Inc. Available via:

http://www.edsimulation.com/ [accessed Jan. 3, 2011].

Martin, James N., Systems Engineering Guidebook: A Process for Developing Systems and Products, CRC Press, Inc.: Boca Raton, FL, 1996.

Press Release: MYMIC LLC awarded new phase ii simulation contract award. Feb. 11, 2010. Available via:

http://www.mymic.net/news.php?id=31 [accessed Jan. 3, 2011]

GameTT. MYMIC LLC. Available via:

http://www.mymic.net/answers.php?id=4 [accessed Jan. 3, 2011]

Digital Imaging and Communications in Medicine (DICOM). The

Association of Electrical and Medical Imaging Equipment Manufacturers 
[NEMSIS 2010]

[NFPA 2010]

[NIEM 2011]

[NIH 2010a]

[NIH 2010b]

[NIH 2010c]

[NIH 2010d]

[NIH 2010e]

[NISAC 2007]

[NISAC 2007]

[NIST 2010a]

[NIST 2010b]

[NYU-CCPR 2009]
(NEMA). Available via: http://medical.nema.org/ [Accessed Dec. 12, 2010]

NEMSIS Tools. National EMS Information System (NEMSIS). Available via: http://www.nemsis.org/ [Accessed Dec. 12, 2010] NFPA 472: Standard for Competence of Responders to Hazardous Materials/Weapons of Mass Destruction Incidents. National Fire Protection Association (NFPA). Available via:

http://www.nfpa.org/aboutthecodes/AboutTheCodes.asp?DocNum=472\&c ookie\%5Ftest=1 [Accessed Dec. 12, 2010]

National Information Exchange Model (NIEM). NIEM.gov. Available via: http://www.niem.gov/ [accessed Jan. 24, 2011].

Clinical Data Repository (CDR). National Institutes of Health (NIH). Available via: http://www.cc.nih.gov/isd/cdr.html [Accessed Dec. 12, 2010]

Directory of Health Organizations. National Institutes of Health (NIH). Available via: http://dirline.nlm.nih.gov/ [Accessed Dec. 12, 2010] Drug Information Portal. National Institutes of Health (NIH). Available via: http://www.nlm.nih.gov/pubs/factsheets/druginfoportalfs.html [Accessed Dec. 12, 2010]

Haz-Map: Occupational Exposure to Hazardous Agents. National Institutes of Health (NIH). Available via: http://hazmap.nlm.nih.gov/ [Accessed Dec. 12, 2010]

TOXNET: Toxicology Data Network. National Institutes of Health (NIH). Available via: http://www.nlm.nih.gov/pubs/factsheets/toxnetfs.html [Accessed Dec. 12, 2010]

NISAC, 2007. Uncertainty Analysis of Pandemic Influenza Impacts on National Infrastructure: Supplement to the National Population and Infrastructure Impacts of Pandemic Influenza Report. National Infrastructure Simulation \& Analysis Center, Infrastructure Analysis and Strategy Division Office of Infrastructure Protection, Department of Homeland Security, 15 October 2007. Available on-line via: www.sandia.gov/nisac/docs/UncertaintyAnalysis.doc. [Accessed July 21, 2010]

NISAC, 2007. Uncertainty Analysis of Pandemic Influenza Impacts on National Infrastructure: Supplement to the National Population and Infrastructure Impacts of Pandemic Influenza Report. National Infrastructure Simulation \& Analysis Center, Infrastructure Analysis and Strategy Division Office of Infrastructure Protection, Department of Homeland Security, 15 October 2007. Available via:

http://www.sandia.gov/nisac/docs/UncertaintyAnalysis.doc [accessed July 21, 2010]

FIPS Publications. National Institute of Standards and Technology

(NIST). Available via:

http://csrc.nist.gov/publications/PubsDrafts.html\#800-66-Rev1[Accessed

Dec. 12, 2010]

"Modeling and Simulation for Emergency Management and Healthcare Systems." NISTIR 7684. National Institute of Standards and Technology (NIST). Gaithersburg, MD. 2010. Available via: http://www.mel.nist.gov/div826/msid/sima/simconf/pubs.htm [Accessed 25 April 2011]

Planning with Large Agent-Networks against Catastrophes (PLAN C). The 
[OASIS 2011a]

[OASIS 2011b]

[OGC 2011a]

[OGC 2011c]

[OMG 2011]

[Optima 2011]

[ProModel 2010a]

[ProModel 2010b]

[RAND 2010]

[Rinaldi 2004]

[SIMBIOS 2010]

[Stanford 2010]

[Stroud 2007]

[THEDATAWEB 2010]

[USU 2010]

[WMO 2010a]
Center for Catastrophe Preparedness \& Response, New York University. Available via: http://www.nyu.edu/ccpr/laser/plancinfo.html [accessed Jan. 3, 2011]

Common Alert Protocol (CAP). Organization for the Advancement of Structured Information Standards (OASIS). Available via: http://www.oasis-emergency.org/cap [accessed Jan. 15, 2011]. Emergency Data Exchange Language (EDXL). Organization for the Advancement of Structured Information Standards (OASIS). Available via: http://xml.coverpages.org/edxl.html [accessed Mar. 25, 2011]. CityGML: OpenGIS City Geography Markup Language Encoding Standard. Open Geospatial Consortium, Inc. (OGC). Available via: http://www.opengeospatial.org/standards/citygml [accessed Jan. 15, 2011]. Simple Feature Access. Open Geospatial Consortium, Inc. (OGC). Available via: http://www.opengeospatial.org/standards/sfa [accessed Mar. 25, 2011].

OMG Systems Modeling Language (SysML). Object Management Group, Inc. (OMG). Available via: http://omgsysml.org/ [accessed Mar. 25, 2011].

Optima Predict. The Optima Corporation. Available via: http://www.theoptimacorporation.com/optima-predict [accessed Jan. 3, 2011].

ED Simulator ${ }^{\mathrm{TM}}$ - because “Best Practices don't always yield Best Results@. ProModel Corporation. Available via: http://www.promodel.com/products/edsimulator/ [accessed Jan. 3, 2011]. MedModel - The Industry Standard for Healthcare Simulation. ProModel Corporation. Available via: http://www.promodel.com/products/medmodel/ [accessed Jan. 3, 2011]. RAND Databases and Research Tools. RAND Corporation. Available via: http://www.rand.org/about/tools.html [Accessed Dec. 12, 2010] Rinaldi, S. (2004). "Modeling and simulating critical infrastructure and their interdependencies." $37^{\text {th }}$ Hawaii International Conf. on System Science, IEEE Available via: http://portal.acm.org/citation.cfm?id=962881 [accessed Jan9, 2011] Simbios: NIH Center for Biomedical Computation at Stanford. Available via: http://simbios.stanford.edu/ [accessed Dec. 29, 2010] Simulation Modalities. Center for Immersive and Simulation-based Learning, Stanford School of Medicine. Available via: http://cisl.stanford.edu/what_is/sim_modalities/[accessed Dec. 29, 2010] Stroud P.D., S.Y. Del Valle, S.J. Sydoriak, J.M. Riese, and S.M. Mniszewski, 2007. Spatial Dynamics of Pandemic Influenza in a Massive Artificial Society. Journal of Artificial Societies and Social Simulation 10(4)9. Available on-line via: http://jasss.soc.surrey.ac.uk/10/4/9.html. [Accessed July 21, 2010] TheDataWeb. U.S. Census Bureau. Available via: http://www.thedataweb.org/browser.html [Accessed Dec. 12, 2010] National Capital Area Medical Simulation Center. Uniformed Services University. Available via: http://simcen.usuhs.edu/ [accessed Dec. 29, 2010]

A Guide to the Code Form FM 92-IX Ext. GRIB. World Health Organization. Available via:

http://www.wmo.int/pages/prog/www/WDM/Guides/Guide-binary-2.html 
[YNHHS 2010]

[accessed Nov. 3, 2010].

Weapons of Mass Destruction (WMD), Emergency Management and Medical Web Sites. Available via:

http://www.ynhhs.org/emergency/US_DHHS_web_sites.pdf [Accessed

Dec. 12, 2010] 